\title{
Phyllanthus (Phyllanthaceae) no estado do Rio de Janeiro ${ }^{1}$
}

\author{
Phyllanthus (Phyllanthaceae) in the State of Rio de Janeiro
}

\author{
Erika Ramos Martins ${ }^{2,5}$, Letícia Ribes de Lima $^{3}$ \& Inês Cordeiro ${ }^{4}$
}

\begin{abstract}
Resumo
Phyllanthus ocorre em quase todas as regiões do planeta. No Brasil são registradas cerca de 100 espécies, que ocorrem em florestas, cerrados, campos e nas caatingas. O objetivo do presente trabalho foi estudar as espécies de Phyllanthus ocorrentes no estado do Rio de Janeiro, contribuindo para o Projeto "Flora Fanerogâmica do Estado do Rio de Janeiro". Para cada uma das espécies é indicada a obra original, coleções-tipo, distribuição geográfica, período de floração e frutificação, além de comentários sobre caracteres morfológicos diagnósticos. Além disso, foram propostos alguns novos sinônimos e apresentadas ilustrações originais de algumas espécies, bem com uma chave de identificação para as 20 espécies do gênero encontradas no estado.
\end{abstract}

Palavras-chave: Euphorbiaceae s.l., florística, taxonomia.

\begin{abstract}
Phyllanthus occurs in tropical and temperate regions of the world. Around 100 species are recorded to Brazil, growing in forests, cerrados, grasslands and caatingas. The aim of this study was to survey the species of Phyllanthus from the State the Rio de Janeiro and thus contribute to the project Flora Fanerogâmica do Rio de Janeiro. For each species is indicated the original publication, type collections, geographic distribution, period of flowering and fruiting, and comments on diagnostic characters. Also some new synonyms are proposed and original illustrations of some species are presented, as well as an identification key to the 20 species of the genus found in the State.
\end{abstract}

Key words: Euphorbiaceae s.l., floristics, taxonomy.

\section{Introdução}

Phyllanthaceae foi formalmente restabelecida por Chase et al. (2002), com base em estudos filogenéticos com dados moleculares, já em parte previamente divulgados em seu trabalho anterior (Chase et al. 1993). Apresenta 55 gêneros e 1745 espécies dispersas por todo o globo, principalmente nas regiões tropicais, tendo como características diagnósticas as flores unissexuadas, o ovário geralmente 3-carpelar, lóculos do ovário biovulados, estiletes bífidos e frutos esquizocárpicos (Judd 2009).

Wurdack et al. (2004) e Hoffmann et al. (2006) a subdividiram em duas subfamílias, Phyllanthoideae, caracterizada principalmente pela epiderme desprovida de células taníferas, inflorescências glomeruliformes, flores com ou sem pétalas e frutos geralmente deiscentes (cápsulas de deiscência explosiva), raramente bagas ou drupas, que no Brasil está representada pelos gêneros Phyllanthus, Amanoa, Savia, Discocarpus, Gonatogyne, Meineckia Flueggea e Astrocasia; e a subfamília Antidesmatoideae, caracterizada pela presença de células taníferas na epiderme, inflorescências espiciformes, flores geralmente sem pétalas, frutos indeiscentes (drupas) ou tardiamente deiscentes, não explosivos, representada no Brasil pelos gêneros Hieronyma e Richeria

Phyllanthus é o principal representante da família Phyllanthaceae e possui aproximadamente 800 espécies (Govaerts et al. 2000; Webster 1956, 2002a,b), sendo o maior e mais diversificado gênero dessa família (Webster \& Carpenter 2002). Suas espécies ocorrem em todas as regiões do

\footnotetext{
${ }^{1}$ Parte do projeto de Mestrado da primeira autora.

${ }^{2}$ Universidade Federal de São Carlos, Centro de Ciências Agrárias, Programa de Pós-graduação em Agricultura e Ambiente, Araras, SP, Brasil.

${ }^{3}$ Universidade Federal de Alagoas, Instituto de Ciências Biológicas e da Saúde, Maceió, AL, Brasil.

${ }^{4}$ Instituto de Botânica, Núcleo de Curadoria do Herbário de São Paulo, Secretaria do Meio Ambiente, São Paulo, SP, Brasil.

${ }^{5}$ Autor para correspondência: eramosmartins@hotmail.com
} 
planeta, sendo 200 delas encontradas nas Américas, 100 na África e 70 em Madagascar. As demais se distribuem pela Ásia e Austrália (Radcliffe-Smith 2001). No Brasil, o último levantamento realizado por Webster (2002b) aponta para a ocorrência de 107 espécies de Phyllanthus, e 99 de acordo com a Lista de espécies da flora do Brasil (Secco et al. 2013), que ocorrem em todos os tipos de vegetação (Silva \& Sales 2004, 2007), das quais um quarto são encontradas, principalmente, nos campos rupestres, cerrados e caatingas.

O presente estudo teve como objetivo principal realizar o levantamento das espécies de Phyllanthus que ocorrem no estado do Rio de Janeiro.

\section{Material e Métodos}

O estado do Rio de Janeiro localiza-se entre as latitudes $20^{\circ} 46^{\prime}$ e $23^{\circ} 13^{\prime} \mathrm{S}$ e as longitudes $40^{\circ} 58^{\prime} \mathrm{e}$ $44^{\circ} 47^{\prime} \mathrm{W}$ e tem uma área total de $43.696,054 \mathrm{~km}^{2}$. As altitudes no estado variam desde o nível do mar até 2.792,66 m no seu ponto mais alto, o Pico das Agulhas Negras, no Parque Nacional do Itatiaia, na Serra da Mantiqueira (IBGE 2013).

Os climas encontrados no estado são o tropical, nas áreas mais baixas, e o tropical de altitude, nas regiões serranas, mais elevadas. $\mathrm{Na}$ região metropolitana do Rio de Janeiro, domina o clima tropical semi-úmido, com chuvas abundantes no verão. A temperatura média anual no estado varia de 22 a $24^{\circ} \mathrm{C}$ (Governo do Rio de Janeiro 2013).

Originalmente, a floresta ombrófila densa atlântica era o tipo de vegetação dominante em todo o estado do Rio de Janeiro, porém devido à ocupação agropastoril, o desmatamento modificou sensivelmente essa cobertura original e atualmente as florestas ocupam apenas um décimo do território fluminense, concentrando-se principalmente nas partes mais altas das serras, onde também ocorrem os campos de altitude (Governo do Rio de Janeiro 2013).

Foram analisadas coleções de Phyllanthus depositadas nos principais herbários do Estado do Rio de Janeiro, entre eles os herbários do Jardim Botânico do Rio de Janeiro (RB), da Universidade Federal do Rio de Janeiro (R), da Universidade Federal Rural do Rio de Janeiro (RBR), o Herbário Bradeanum (HB), além de coleções depositadas em outras importantes coleções como as do Instituto de Botânica (SP), da Universidade de São Paulo (SPF) e da Universidade Estadual de Campinas (UEC) (acrônimos de acordo com Thiers 2013), além de observadas populações de algumas espécies no campo. Os comentários sobre a distribuição geográfica e hábitats preferenciais das espécies foram baseados nas informações contidas nos rótulos das exsicatas, nas observações feitas em campo e também em dados levantados de literatura específica. A descrição do gênero é aquela elaborada para a Flora Fanerogâmica de São Paulo (Martins \& Lima 2012). As ilustrações aqui apresentadas foram elaboradas por desenhista especializado, com base nos materiais estudados e os detalhes de flores, frutos e sementes foram ilustrados sob estereomicroscópio acoplado à câmara clara.

Na tentativa de contribuir para a conservação das espécies, as mesmas foram classificadas nas categorias propostas pela IUCN - International Union for Conservation of Nature - (2011) considerando todo território nacional: 1. LC: pouco preocupante; 2. VU: vulnerável; 3. EN: ameaçada, de acordo com a extensão de sua ocorrência, número de coletas, data do último registro de coleta, ocorrência em área de conservação e endemismo.

\section{Resultados e Discussão}

\section{Morfologia}

As espécies ocorrentes no estado do Rio de Janeiro são geralmente subarbustivas a herbáceas, e apenas Phyllanthus acuminatus Vahl., P. cladotrichus Müll. Arg., P. juglandifolius Willd., P. riedelianus Müll. Arg. e P. umbratus Müll. Arg. desenvolvemse como arbustos ou mesmo pequenas árvores. Há espécies com ou sem ramificação filantoide, porém nenhuma delas apresenta os ramos modificados em cladódios. As folhas são em geral membranáceas, mas subcartáceas em P. caparaoensis G.L. Webster, subcoriáceas em $P$. riedelianus e coriáceas em $P$. rosmarinifolius Müll. Arg., com margem plana ou revoluta. As inflorescências são unissexuais ou bissexuais, com flores solitárias ou com até 20 flores por inflorescência, como ocorre em P. umbratus. As flores possuem cinco a seis sépalas, de coloração esbranquiçada, amarelada ou esverdeada, raramente vináceas, como em $P$. cladotrichus e $P$. orbiculatus L.C. Rich. $\mathrm{O}$ androceu é formado por dois estames em $P$. amarus Schumach, P. cladotrichus e $P$. umbratus, quatro a seis em P. juglandifolius, cinco em P. tenellus Roxb. e três nas demais espécies. As flores masculinas possuem disco comumente segmentado (exceto P. cladotrichus e $P$. juglandifolius), ao passo que o disco feminino é usualmente inteiro, exceto em $P$. amarus, $P$. orbiculatus e P. umbratus, onde essa estrutura varia de lobada ou segmentada. As sementes possuem testa lisa, estriada ou verruculosa. 
Tratamento taxonômico

Phyllanthus L., Sp. Pl. 2: 981. 1753.

Ervas a subarbustos, raramente arbustos ou arvoretas, monoicos ou mais raramente dioicos; indumento, quando presente, de tricomas simples; ramos pinatiformes (não ramificados) a bipinatiformes (ramificados), às vezes modificados em cladódios. Folhas presentes unicamente nos ramos secundários ou também no eixo principal, alternas, geralmente dísticas, raramente espiraladas, simples, inteiras, pecioladas, estipuladas, quando presentes apenas nos ramos secundários, reduzidas a estruturas escamiformes no eixo principal, caracterizando a ramificação filantoide. Inflorescências axilares, cimosas, raramente espiciformes; címulas unissexuais ou bissexuais, às vezes flores solitárias, monoclamídeas. Flores masculinas com sépalas 5-6, geralmente esverdeadas, raramente avermelhadas ou vináceas; disco com 5-6 glândulas, raramente inteiro; (2-)3-5(-6) estames livres ou unidos, anteras 2-tecas, com deiscência horizontal ou vertical. Flores femininas com sépalas 5-6, geralmente esverdeadas, raramente avermelhadas ou vináceas; disco inteiro, raramente segmentado; gineceu 3-carpelar; lóculos biovulados; estiletes 3 , livres ou unidos na base, geralmente 2-fidos. Fruto cápsula septicida-loculicida, raramente baga ou drupa, liso, raramente ornamentado. Sementes 2 por lóculo, trígonas, lisas ou verrucosas, testa crustácea, castanha.

No estado do Rio de Janeiro foram encontradas 20 espécies de Phyllanthus: P. acuminatus Vahl, P. acutifolius Poir. ex Spreng., P. amarus Schumach. P. arenicola Casar., P. augustinii Baill., P. caparaoensis G.L.Webster, P. caroliniensis Walter, P. cladotrichus Müll. Arg., P. glaziovii Müll. Arg., P. itatiaiensis Brade, P. juglandifolius Willd., P. mocotensis G.L. Webster, P. niruri L., P. orbiculatus Rich., P. riedelianus Müll. Arg., P. rosmarinifolius Müll. Arg., P. subemarginatus Müll. Arg., P. tenellus Roxb., P. umbratus Müll. Arg. e P. urinaria L.

\section{Chave para identificação das espécies de Phyllanthus do estado do Rio de Janeiro}

1. Flores com 6 sépalas.

2. Hábito arbustivo a arborescente; estames completamente unidos pelos filetes.

3. Planta pubescente; folhas membranáceas, ovais ....................... 1. Phyllanthus acuminatus

3'. Planta glabra; folhas subcoriáceas, elípticas 14. Phyllanthus riedelianus

2'. Hábito subarbustivo a herbáceo; estames livres.

4. Folhas orbiculares a largamente ovais; pedicelo das flores masculinas $1,5-3 \mathrm{~mm}$ compr.; flores vináceas; disco das flores femininas segmentado 13. Phyllanthus orbiculatus

4'. Folhas elípticas, oblongas ou obovais; pedicelo das flores masculinas até $1 \mathrm{~mm}$ compr.; flores esverdeadas a amareladas; disco das flores femininas inteiro.

5. Planta sem ramificação filantoide; base das folhas cuneada, margem plana, frutos lisos .. 6. Phyllanthus caroliniensis

5'. Planta com ramificação filantoide; base das folhas assimétrica, cordada, margem revoluta, frutos ornamentados 19. Phyllanthus urinaria

1'. Flores com 5 sépalas.

6. Estames 4 a 6.

7. Arbusto a arvoreta; folhas elípticas a ovais com 51-132 mm de compr.; estames completamente unidos; pedicelo das flores 12-18 mm compr.; cápsula $7 \times 11 \mathrm{~mm}$

\section{Phyllanthus juglandifolius}

7'. Erva a subarbusto; folhas elípticas a obovais com 5-15 mm de compr.; estames livres; pedicelo das flores $1-4 \mathrm{~mm}$ compr., cápsula $1 \times 2 \mathrm{~mm}$ 17. Phyllanthus tenellus

6'. Estames 2 a 3.

8. Folhas com nervação broquidódroma; pedicelo das flores femininas maior que $7 \mathrm{~mm}$ compr. 9. Arbusto a arvoreta, 2,5-7 $\mathrm{m}$ alt.; pecíolos maiores que $3 \mathrm{~mm}$ compr.

10. Base das folhas aguda a arredondada, estípulas $2,5-3,5 \mathrm{~mm}$ compr., lanceoladas, glabras a pubescentes; sépalas vináceas; disco das flores femininas inteiro

7. Phyllanthus cladotrichus

10'. Base das folhas retusa; estípulas $1-1,5 \mathrm{~mm}$ compr., triangulares, glabras; sépalas esverdeadas; disco das flores femininas segmentado ...... 18. Phyllanthus umbratus 
9'. Erva a subarbusto, até $2 \mathrm{~m}$ alt.; pecíolos até $2 \mathrm{~mm}$ compr.

11. Folhas oblongas; disco das flores femininas lobado

5. Phyllanthus augustinii

11'. Folhas ovais; disco das flores femininas inteiro.

12. Caule liso; folhas com ápice acuminado a longo-acuminado; pedicelo das flores masculinas 7-8 mm compr.; flores femininas $2-5 \mathrm{~mm}$ 8. Phyllanthus glaziovii

12'. Caule com emergências em forma de crista ao longo de suas estrias; folhas com ápice agudo; pedicelo das flores masculinas 2,5-3mm compr.; flores femininas 1,5-2 mm compr.

2. Phyllanthus acutifolius

8'. Folhas com nervação cladódroma ou uninérveas; pedicelo das flores femininas até $5 \mathrm{~mm}$ compr.

13. Estames 2, filetes completamente unidos

3. Phyllanthus amarus

13'. Estames 3, filetes livres.

14. Folhas coriáceas, lineares

15. Phyllanthus rosmarinifolius

14'. Folhas membranáceas ou subcartáceas, ovais, orbiculares, elípticas ou oblongas.

15. Ramos com emergências em forma de crista ao longo das estrias do caule; folhas subcartáceas 6. Phyllanthus caparaoensis

15'. Ramos sem emergências em forma de crista ao longo das estrias do caule; folhas membranáceas.

16. Ramos pubescentes; folhas com ápice acuminado a agudo; estípulas elípticas a estreitamente triangulares 4. Phyllanthus arenicola

16'. Ramos glabros; folhas com ápice arredondado ou obtuso, às vezes apiculado; estípulas triangulares a lineares.

17. Planta com ramificação filantoide; folhas oblongas ou obovais.

18. Base das folhas assimétrica a cordada, margem plana

13. Phyllanthus niruri

18'. Base das folhas cuneada, margem revoluta ..... 12. Phyllanthus mocotensis

17'. Planta sem ramificação filantoide; folhas falcadas ou orbiculares.

19. Folhas falcadas, ápice e base agudo, não apiculado; nervação cladodróma; pecíolos ca. 0,5 mm compr.; pedicelo das flores masculinas 1-2 mm compr.

10. Phyllanthus itatiaiensis

19'. Folhas orbiculares, ápice arredondado, apiculado; base arredondada, nervação broquidódroma; pecíolos 1,5-2,0 compr.; pedicelo das flores masculinas 2,5-3 mm compr. 17. Phyllanthus subemarginatus

1. Phyllanthus acuminatus Vahl, Symb. Bot 2: 95. 1971. Tipo: TRINIDADE E TOBAGO, 1778, $J$. Ryan s.n. (holótipo BM n.v., fotografia do holótipo em BM! (BM000947320)). Fig. 1a-b

Arvoretas monoicas, 1,5-9 m alt., ramificação filantoide; caule liso, ramos cilíndricos, pubescentes. Folhas membranáceas, levemente discolores, 14-35 $\times$ 5-20 mm, ovais; ápice agudo a acuminado, às vezes apiculado; base retusa a arredondada; face adaxial pubescente, face abaxial glabra a pubescente; margem plana; nervação broquidódroma; pecíolos 1,5-3 mm compr.; estípulas ca. $1 \mathrm{~mm}$ compr., estreitamente triangulares, pubescentes. Inflorescências em címulas axilares, compostas por mais de 6 flores ou, às vezes, flores solitárias; brácteas ca. $1 \mathrm{~mm}$ compr., lanceoladas. Flores masculinas ca. $0,5 \mathrm{~mm}$ compr.; sépalas 6, ca. $0,5 \mathrm{~mm}$ compr., elípticas, membranáceas; estames 3 , filetes completamente unidos formando uma coluna; anteras com deiscência horizontal; disco 3-lobado; pedicelo ca. $2 \mathrm{~mm}$ compr. Flores femininas 0,5-1 $\mathrm{mm}$ compr.; sépalas $6,1 \mathrm{~mm}$ compr., elípticas; ovário $0,5 \mathrm{~mm}$ compr., estiletes 3,2 -fidos até a metade; disco inteiro; pedicelo 10-11 mm compr. Cápsulas 4× 2-4 mm. Sementes 2-2,5 mm compr., avermelhadas, lisas.

Nomes populares: conambi, carobinha, tinguí, mata-peixe (Silva \& Sales 2007).

Material selecionado: Teresopólis, VII.1966, fl., $M$. Emmerich 2855 (R).

Phyllanthus acuminatus pode ser confundida com $P$. riedelianus, pois ambas são arvoretas, apresentam ambas as flores com seis sépalas, címulas com mais de seis flores e três estames com filetes unidos, formando uma coluna. Porém, $P$. acuminatus possui ramos bipinatiformes e folhas 

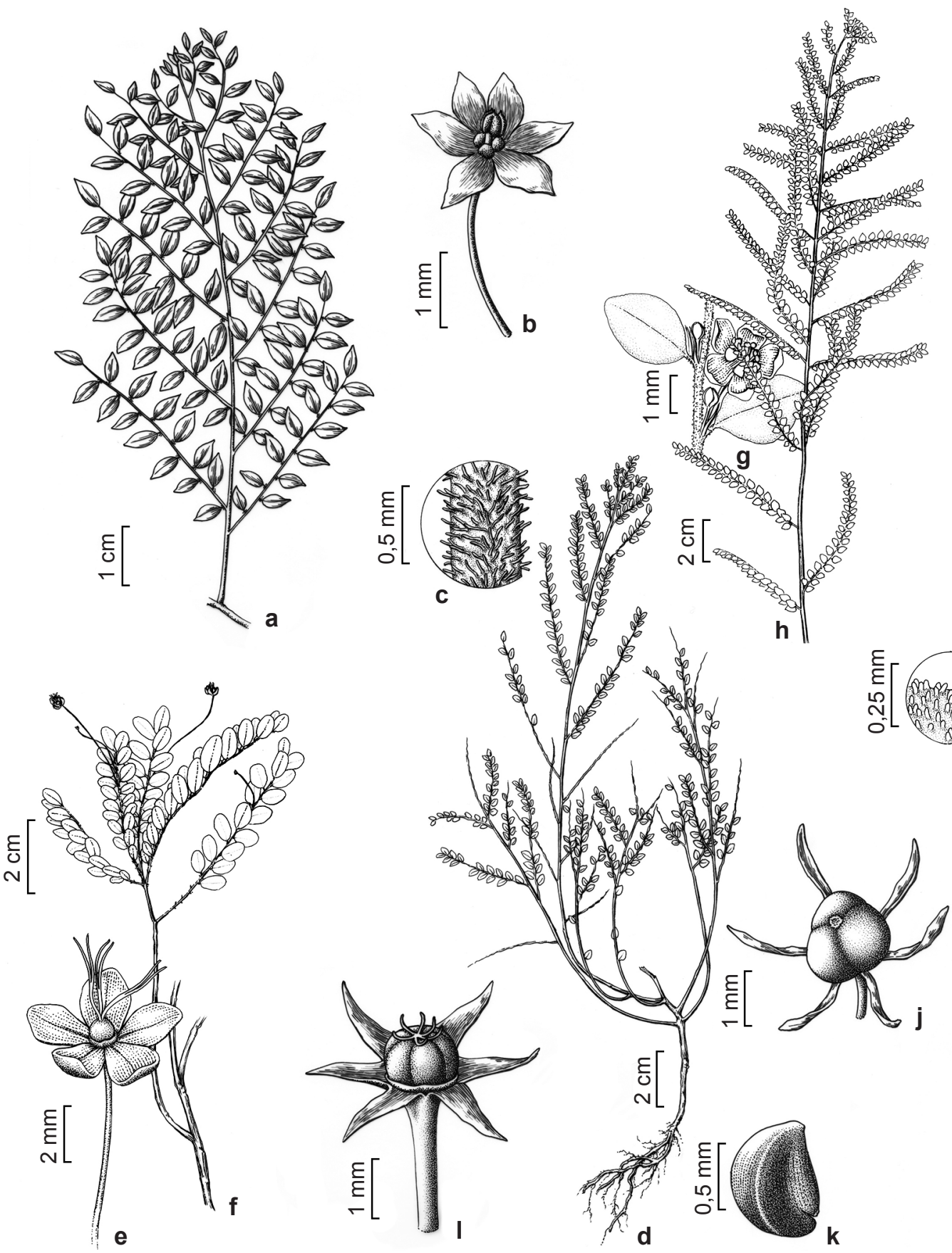

Figura 1 - a-b. Phyllanthus acuminatus - a. ramo; b. flor masculina. c-d. Phyllanthus arenicola - c. detalhe dos tricomas; d. hábito. e-f. Phyllanthus augustinii - e. flor feminina; f. ramo. g-i. Phyllanthus caparaoensis - g. detalhe da inflorescência; h. ramo; i. detalhe das emergências do ramo. j-1. Phyllanthus caroliniensis - j. fruto; k. semente; 1. flor feminina. (a-b F. Tamasetto 177; c-d W. Hermes 5874; e-f V. Demuner 1397; g-i V. Demuner et al. 3879; j-1 A.S. Grotta s.n. (SP385033)).

Figure 1 - a-b. Phyllanthus acuminatus - a. branch; b. male flower. c-d. Phyllanthus arenicola - c. detail of trichomes; d. habit. e-f. Phyllanthus augustinii - e. female flower; f. branch. g-i. Phyllanthus caparaoensis - g. detail of inflorescence; h. branch; i. detail of emergencies branch. j-1. Phyllanthus caroliniensis - j. fruit; k. seed; 1. female flower. (a-b F. Tamasetto 177; c-d W. Hermes 5874; e-f V. Demuner 1397; g-i V. Demuner et al. 3879; j-1 A.S. Grotta s.n. (SP385033)). 
membranáceas, com base variando de retusa a arredondada, e geralmente ocorre em florestas estacionais, enquanto $P$. riedelianus possui ramos pinatiformes e folhas subcoriáceas, com base variando de aguda a atenuada e ocorre no interior de floresta ombrófila.

Espécie exclusiva das Américas, ocorrendo desde o norte do México até o norte da Argentina, incluindo Antilhas (Webster 2003; Silva \& Sales 2007). No Brasil é registrado para as Regiões Norte (Pará, Amazonas, Acre e Rondônia), Nordeste (Paraíba, Pernambuco e Bahia), Centro-Oeste (Goiás e Distrito Federal) e Sudeste (Espírito Santo, Rio de Janeiro, Minas Gerais e São Paulo), geralmente em floresta estacional semidecidual (Secco et al. 2013). Coletada com flores e frutos nos meses de março e maio e de outubro a dezembro. O status de conservação é pouco preocupante (LC), por ser uma espécie de ampla distribuição, que possui um número significativo de coletas, várias delas recentes. Além disso, Phyllanthus acuminatus ocorre em áreas de conservação como o Parque Nacional da Serra dos Órgãos.

2. Phyllanthus acutifolius Poir. ex Spreng, Syst. Veg. 3: 21. 1826. Tipo: BRASIL. Herb. Poiret (holótipo P n.v., referido por Webster [2002b]).

Subarbustos a arbustos monoicos, 0,5-0,8 $\mathrm{m}$ alt., sem ramificação filantoide; caule com emergências em forma de crista ao longo das estrias; ramos cilíndricos, glabros. Folhas membranáceas, discolores, 8-23 × 5-12 mm, ovais; ápice agudo, base retusa a arredondada; faces adaxial e abaxial glabras; margem levemente revoluta; nervação broquidodróma; pecíolos 0,5-1 mm compr.; estípulas 0,5-1 mm compr., lanceoladas, glabras. Inflorescência em címulas axilares, compostas por flores solitárias; brácteas 0,5-1 mm compr., lanceoladas. Flores masculinas 1-2 mm compr.; sépalas 5, 0,5-1 mm compr., elípticas a ovais, membranáceas; estames 3 , filetes completamente livres; anteras com deiscência vertical; disco 5-lobado; pedicelo 2,5-3 mm compr. Flores femininas 1,5-2 mm compr.; sépalas 5, 0,5-1 mm compr., elípticas a ovais, membranáceas; ovário 0,5 mm compr., estiletes 3, 2-fidos até a metade; disco inteiro; pedicelo 7-8 mm compr. Cápsulas não observadas. Sementes não observadas.

Material selecionado: Resende (Parque Nacional do Itatiaia), V.1985, fl., G. Martinelli 10773 (RB).

Phyllanthus acutifolius é muito semelhante a $P$. glaziovii. O tamanho das folhas $(8-23 \times 5-12$ $\mathrm{mm}$ na primeira, $15-45 \times 5-16 \mathrm{~mm}$ na segunda), com formato oval e base variando de retusa a arredondada, semelhante em ambos os táxons, dificultam sua distinção. Porém, P. acutifolius apresenta emergências evidentes por todo o ramo, ao passo que em $P$. glaziovii os ramos são lisos.

Espécie endêmica do Brasil encontrada apenas na Região Sudeste, na Serra da Mantiqueira, próximo da divisa entre os estados de Minas Gerais, Rio de Janeiro (Govaerts et al. 2000) e São Paulo (Webster 2002a) em de campo de altitude. Coletada com flores apenas no mês de abril. Seu status de conservação é vulnerável (VU) por ser uma espécie endêmica do Brasil e ser conhecida por pequenas populações ou mesmo por indivíduos isolados em locais pontuais como a Serra da Mantiqueira. Apesar de apresentar coletas recentes, nenhuma foi em área de conservação.

3. Phyllanthus amarus Schum. \& Thonn, Kongl, Danske Vidensk. Selsk. Skr. 4: 195-196. 1829. Tipo: ÁFRICA. Guiné, Schumacher \& Thonning s.n. (holótipo C n.v., referido por Webster [1957]).

Ervas monoicas, 0,2-0,3 m alt.; ramificação filantoide, caule liso, ramos angulosos, glabros. Folhas membranáceas, levemente discolores a discolores, 4-13 × 2-6 mm; oblongas a elípticas; ápice arredondado a retuso; base retusa; face adaxial glabra, face abaxial pubescente; margem plana; nervação cladodróma; pecíolos 0,5-1 mm compr.; estípulas 1-1,5 mm compr., lanceoladas, glabras. Inflorescência em címulas axilares, compostas geralmente por 2 flores, sendo uma feminina e uma masculina; brácteas 1-1,5 mm compr., lanceoladas. Flores masculinas 1,5-2 mm compr.; sépalas 5, 1-1,5 mm compr., obovais a elípticas, membranáceas; estames 2, filetes completamente unidos formando uma coluna; anteras com deiscência horizontal; disco 5-lobado; pedicelo 1-1,5 mm compr. Flores femininas 1,5-2 mm compr.; sépalas 5, 0,5-1 mm compr., elípticas a obovais, membranáceas; ovário $0,5 \mathrm{~mm}$ compr., estiletes 3, 2-fidos apenas no ápice; disco 5-lobado; pedicelo 1-1,5 mm compr. Cápsulas ca. 2,5 × 3 $\mathrm{mm}$. Sementes 0,5-1 mm compr., castanho-claras, estriadas.

Material selecionado: Angra dos Reis IV.2003, fr., C.C. Zysco 314 (HB).

Phyllanthus amarus pode ser confundida com $P$. niruri devido ao hábito herbáceo, folhas oblongas e por ambas as flores possuírem cinco sépalas. Porém, em $P$. amarus as folhas tem base 
retusa, as címulas tem duas flores, uma masculina e outra feminina, o androceu possui dois estames com filetes completamente unidos, e o disco das flores femininas é 5-lobado, enquanto $P$. niruri possui folhas assimétricas na base, címulas com flores solitárias, três estames com filletes livres e disco das flores femininas inteiro.

Táxon pantropical, que apresenta maior a distribuição do gênero (Webster 2002b). No Brasil é registrado para a Região Norte (Roraima, Amapá, Pará, Amazonas e Acre), Nordeste (Maranhão, Ceará, Paraíba, Pernambuco, Bahia e Sergipe), Centro-Oeste (Mato Grosso, Goiás, Distrito Federal e Mato Grosso do Sul), Sudeste (Minas Gerais, São Paulo e Rio de Janeiro) e Sul (Santa Catarina), em floresta ombrófila densa amazônica e atlântica (Secco et al. 2013). Coletada com flores nos meses de fevereiro, março, junho e dezembro e com frutos nos meses de abril e dezembro. Phyllanthus amarus apresenta status de conservação como pouco preocupante (LC) por ser uma espécie de ampla distribuição, que possui um número significativo de coletas, incluindo coletas recentes, porém nenhuma em áreas de conservação.

4. Phyllanthus arenicola Casar. Nov. Stirp. bras. Dec. 88: 92. 1824. Tipo: BRASIL. RIO DE JANEIRO: Taipú. 1839/40, G. Casaretto 1793 (holótipo G n.v., referido por Webster (2002a).

Fig. 1c-d

Ervas monoicas, 0,3-1 m alt.; ramificação filantoide, caule liso, ramos cilíndricos, pubescentes. Folhas membranáceas, levemente discolores, 5-9 × 3-6 mm; ovais; ápice acuminado a agudo; base aguda a arredondada; faces adaxial e abaxial pubescentes; margem levemente revoluta; nervação broquidodróma; pecíolos 1-1,5 mm compr.; estípulas 1,5-2 mm compr., elípticas, a estreitamente triangulares, glabras. Inflorescências em címulas axilares, compostas por 2-3 flores ou, às vezes, flores solitárias; brácteas ca. $1 \mathrm{~mm}$ compr., estreitamente triangulares. Flores masculinas 1-1,5 mm compr.; sépalas 5, 1-1,5 mm compr., elípticas a obovais, membranáceas; estames 3, filetes completamente livres; anteras com deiscência horizontal; disco 5-lobado; pedicelo 2,5-3 mm compr. Flores femininas 1-1,5 mm compr.; sépalas 5, 1-1,5 mm compr., elípticas a obovais; ovário 0,5 mm compr., estiletes 3, 2-fidos até a metade; disco inteiro; pedicelo 3-4 mm compr. Cápsulas ca. 3 x $2 \mathrm{~mm}$. Sementes 1-1,5 mm compr., castanhoamareladas, verruculosas.
Material selecionado: Maricá, VIII.1987, fl., A. Lanze, M.C. Pinheiro \& N. Alves 1768 (R).

Phyllanthus arenicola, assim como $P$. mocotensis, apresenta flores com cinco sépalas e três estames com filetes completamente livres. Porém, $P$. arenicola é uma planta pubescente e o ápice das folhas varia de acuminado a agudo, ao passo que $P$. mocotensis é uma espécie completamente glabra e o ápice das folhas é obtuso e apiculado.

Trata-se de um táxon endêmico do Brasil, onde ocorre apenas na Região Sudeste (Espírito Santo, Minas Gerais e Rio de Janeiro). Encontrada nas restingas e em áreas de transição entre a floresta ombrófila densa atlântica de encosta e os campos de altitude (Secco et al. 2013). Coletada com flores nos meses de janeiro, fevereiro, março e julho e frutos apenas em julho. O status de conservação de Phyllanthus arenicola é pouco preocupante (LC) já que é uma espécie que ocorre em três estados brasileiros e possui um número significativo de coletas, varias delas recentes.

5. Phyllanthus augustinii Baill., Adansonia 5: 354. 1865. Tipo: BRASIL. RIO DE JANEIRO, 1816-1821, Saint-Hilaire 743 (holótipo P n.v., fotografia do holótipo em P!). Fig. 1e-f

Ervas monoicas, 0,4 $\mathrm{m}$ alt.; ramificação filantoide, caule liso, ramos cilíndricos, pubescentes. Folhas membranáceas, levemente discolores, 5-10 × 3-5 mm; oblongas; ápice arredondado, às vezes apiculado; base arredondada, assimétrica; faces adaxial e abaxial glabras; margem levemente revoluta; nervação broquidodróma; pecíolos ca. $1 \mathrm{~mm}$ compr., glabros; estípulas ca. $2 \mathrm{~mm}$ compr., estreitamente triangulares, glabras. Inflorescências em címulas axilares, compostas por flores solitárias; brácteas ca. $1 \mathrm{~mm}$ compr., estreitamente triangulares. Flores masculinas 1,5-2 mm compr.; sépalas 5, 1-1,5 mm compr., obovais, membranáceas; estames 3 , filetes completamente livres; anteras com deiscência horizontal; disco 5-segmentado; pedicelo 5-6 mm compr. Flores femininas 1,5-2 mm compr.; sépalas 5, 1,5-2 mm compr., obovais; ovário ca. 1 mm compr., estiletes 3, 2-fidos a partir da metade; disco 5-lobado; pedicelo ca. 22 mm compr. Cápsulas não observadas. Sementes não observadas.

Material selecionado: Rio de Janeiro, 1816 à 1821, fl., A. Saint-Hilaire $743(\mathrm{P})$.

Material adicional examinado: ESPÍRITO SANTO: Santa Teresa, IX.2000, fl., V. Demuer \& E. Bausen 1397 (MBML). 
Phyllanthus augustinii pode ser confundida com $P$. niruri devido à semelhança das folhas, que são oblongas, membranáceas, levemente discolores e com ápice arredondado, flores com cinco sépalas e androceu com três estames com filetes completamente livres em ambas as espécies dificultam sua distinção. Porém em $P$. augustinii as flores femininas são longamente pediceladas (ca. $20 \mathrm{~mm}$ compr.) e possuem disco 5 lobado, enquanto em $P$. niruri as flores femininas tem pedicelo de até $5 \mathrm{~mm}$ compr. e disco inteiro. Outra característica marcante são os estiletes que excedem o tamanho das sépalas, o que não ocorre nas outras espécies do Rio de Janeiro, que possuem os estiletes, de maneira geral, bem menores que as sépalas.

Espécie endêmica do Brasil encontrada apenas na Região Sudeste, nos estados do Espírito Santo e Rio de Janeiro, em floresta ombrófila densa atlântica (Secco et al. 2013). Coletada com flores apenas em setembro. Phyllanthus augustinii pode ser considerada como ameaçada (EN) por ter apenas dois registros de coletas, ambos fora de áreas de conservação.

6. Phyllanthus caparaoensis G.L. Webster, Lundellia 5: 19. 2002. Tipo: BRASIL, MINAS GERAIS/ESPÍRITO SANTO: Serra do Caparaó, 1879, H. Wawra 1039 (holótipo US n.v., fotografia do holótipo em US!).

Fig. 1g-i

Ervas monoicas, $0,3-0,5 \mathrm{~m}$ alt.; ramificação filantoide, caule com emergências em forma de crista ao longo das estrias, ramos cilíndricos, glabros. Folhas subcartáceas, discolores, 1,5-6×1,5-6 mm; circulares a elípticas; ápice arredondado; base arredonda; face adaxial glabra; face abaxial pubescente; margem revoluta; nervação broquidodróma; pecíolos 1-1,5 mm compr., pubescentes; estípulas 1-1,5 mm compr., estreitamente triangulares, pubescentes. Inflorescências em címulas axilares, compostas por flores solitárias; brácteas ca. $1 \mathrm{~mm}$ compr., lanceoladas. Flores masculinas 1,5-2 mm compr.; sépalas $5,1-1,5 \mathrm{~mm}$ compr., obovais, membranáceas; estames 3 , filetes completamente livres, anteras com deiscência horizontal; disco 5-segmentado; pedicelo 1,5-2 mm compr. Flores femininas 1,5-2 mm compr.; sépalas 5, 1,5-2 mm compr., obovais; ovário ca. $1 \mathrm{~mm}$ compr., estiletes 3, 2-fidos a partir da metade; disco inteiro; pedicelo 1,5-2 mm compr. Cápsulas ca. 3 x $3 \mathrm{~mm}$. Sementes 1-1,5 mm compr., castanhas, lisas.

Material selecionado: Macaé, IV.1985, fl. e fr., $G$. Martinelli, C. Farney \& S. Pessoa 10681 (SP).
Phyllanthus caparaoensis possui folhas circulares a elípticas, cinco sépalas em ambas as flores e androceu formado por três estames com filetes completamente livres, assim como observado em $P$. subemarginatus, porém suas folhas são subcartáceas, discolores, com face abaxial e pecíolos pubescentes. Além disso, o pedicelo das flores femininas possui cerca de 8 $\mathrm{mm}$ de comprimento e as sementes são lisas. Em contrapartida, P. submarginatus apresenta folhas membranáceas, levemente discolores, com face abaxial e pecíolos glabros, o pedicelo das flores femininas varia de 4 a $5 \mathrm{~mm}$ de comprimento e as sementes são verruculosas.

Espécie encontrada apenas na Serra do Caparaó, entre os estados de Minas Gerais e Espírito Santo, onde ocorre em áreas de cerrado e nos campos de altitude, porém há registros bibliográficos de coleta no estado do Rio de Janeiro. Coletada com flores de janeiro a março, julho, setembro, outubro e novembro e frutos nos meses de janeiro, agosto e novembro. Phyllanthus caparaoensis apresenta status de conservação pouco preocupante (LC), já que possui um número significativo de coletas, sendo muitas delas recentes. Além disso, P. caparaoensis ocorre em áreas de conservação, como o Parque Nacional do Caparaó.

7. Phyllanthus caroliniensis Walter, Fl. Carol. 228. 1788. Tipo: Herb. Thomas Walter 83 (holótipo BM n.v., referido por Webster [1956]). Fig. 1j-1

Ervas monoicas, 0,1-0,4 m alt.; sem ramificação filantoide, caule liso, ramos cilíndricos, glabros. Folhas membranáceas, concolores a levemente discolores, 8-15 × 3-8 mm; elípticas a obovais; ápice arredondado; base cuneada; face adaxial pubescente; face abaxial glabra; margem plana, nervação cladodróma; pecíolos 0,5-2 mm compr.; estípulas 1-1,5 mm compr., estreitamente triangulares, glabras. Inflorescências em címulas axilares, compostas por 2-3 flores, às vezes, flores solitárias; brácteas $1-1,5 \mathrm{~mm}$ compr., estreitamente triangulares. Flores masculinas $0,5-1$ $\mathrm{mm}$ compr.; sépalas $6,0,5-1 \mathrm{~mm}$ compr., ovais, membranáceas; estames 3 , filetes completamente livres, anteras com deiscência horizontal; disco 6-lobado; pedicelo 0,5-1,0 $\mathrm{mm}$ compr. Flores femininas 1-2 mm compr.; sépalas $6,1-2 \mathrm{~mm}$ compr., lanceoladas, membranáceas; ovário ca. 0,5 mm compr., estiletes 3, 2-fidos até a metade; disco inteiro; pedicelo ca. $0,5 \mathrm{~mm}$ compr. Cápsulas ca. 
$1 \times 2 \mathrm{~mm}$. Sementes 1-1,5 mm compr., amarelo acastanhadas, verruculosas.

Material selecionado: Rio de Janeiro, X.1944, st., O.C. Goes 641 (RB).

Phyllanthus caroliniensis pode ser confundida com $P$. niruri e $P$. tenellus, porém possui flores femininas com pedicelos com até $0,5 \mathrm{~mm}$ compr., com seis sépalas, enquanto nessas duas espécies as flores possuem cinco sépalas e os pedicelos das flores femininas variam de 2 a $5 \mathrm{~mm}$ de comprimento.

Espécie amplamente distribuída nas Américas, estendendo-se desde o Sudeste dos Estados Unidos até Argentina, incluindo Antilhas (Silva \& Sales 2007). No Brasil, ocorre nas Regiões Norte (Amapá, Pará, Amazonas, Acre e Rondônia), Nordeste (Pernambuco e Bahia), Sudeste (Espírito Santo, Minas Gerais, Rio de Janeiro e São Paulo) e Sul (Paraná e Santa Catarina) (Secco et al. 2013), onde cresce, de acordo com Silva \& Sales (2007), em floresta ombrófila densa atlântica, em áreas de Cerrado (nas matas de galeria), de Caatinga e nas florestas montanas ("brejos de altitude"), borda de florestas estacionais, e também como planta ruderal, em terrenos abandonados. Coletada com flores e frutos de fevereiro a maio e em novembro. Seu status de conservação é pouco preocupante (LC) por apresentar ampla distribuição, e um número significativo de coletas, sendo varias recentes.

8. Phyllanthus cladotrichus Müll. Arg., Linnaea 32: 25. 1863. Tipo: BRASIL. RIO DE JANEIRO: L. Riedel s.n. (holótipo B n.v., fotografia do holótipo em F! (F0BN005022 F); isótipo P, fotografia do isótipo em $\mathrm{P}$ !).

Fig. 2a

Arbustos a arvoretas monoicos, 2,5-7 m alt.; sem ramificação filantoide, caule liso, ramos cilíndricos, achatados apenas na porção terminal, pubescentes. Folhas membranáceas, levemente discolores, 40-120 × 15-60 mm; elípticas; ápice cuspidado a acuminado; base aguda a arredondada; faces adaxial e abaxial glabras; margem levemente revoluta; nervação broquidodróma; pecíolos 3-5 mm compr.; estípulas 2,5-3,5 mm compr., lanceoladas, glabras a pubescentes. Inflorescências em címulas axilares, compostas por até 4 flores, às vezes, flores solitárias; brácteas ca. $1,5 \mathrm{~mm}$ compr., estreitamente triangulares, glabras a pubescentes. Flores masculinas $1-1,5 \mathrm{~mm}$ compr.; sépalas $5,1-1,5 \mathrm{~mm}$ compr., largamente ovais, membranáceas, vináceas; estames 2 , filetes completamente unidos formando uma coluna, anteras com deiscência horizontal; disco inteiro; pedicelo 4-6 cm compr. Flores femininas 1,5-2 mm compr.; sépalas 6, 1,5-2 mm compr., elípticas a ovais, membranáceas, vináceas; ovário ca. 0,5 mm compr., estiletes 3, 2-fidos desde a base; disco inteiro; pedicelo 7-18 cm compr. Cápsulas 4-7 × 5-10 mm. Sementes 4-6 mm compr., castanhas, estriadas.

Nome popular: muxita

Material selecionado: Guapimirim, III.1992, fl., C.M. Vieira 215 (RB).

Phyllanthus cladotrichus pode ser reconhecida por seu hábito que varia de pequeno arbusto a arvoreta, pelo indumento presente nos ramos, pelas folhas que variam de $40-120 \mathrm{~mm}$ de comprimento e 1,5 a $6 \mathrm{~cm}$ de largura, pela cor vinácea das flores e o longo pedicelo das flores femininas, variando de 7 a $18 \mathrm{~cm}$ de comprimento, características únicas entre as espécies de Phyllanthus ocorrentes no estado do Rio de Janeiro.

Espécie endêmica do Brasil, onde ocorre no Nordeste (Bahia) e Sudeste (Espírito Santo, Minas Gerais e Rio de Janeiro), principalmente, em áreas de floresta ombrófila densa atlântica (Secco et al. 2013). Coletada com flores nos meses de fevereiro, março, junho, novembro e dezembro e com frutos nos meses de março, junho, setembro e dezembro. Seu status de conservação é vulnerável (VU) por ser uma espécie endêmica do Brasil e conhecida por pequenas populações ou por indivíduos isolados. Apesar de possuir coletas recentes, nenhuma foi em áreas de conservação.

9. Phyllanthus glaziovii Müll. Arg., Fl. bras. 11(2): 41, pl.8. 1873. Tipo: BRASIL. RIO DE JANEIRO: A.F.M. Glaziou 2892 (holótipo BR n.v., fotografia do holótipo em BR!; isótipo P n.v., fotografia do isótipo em $\mathrm{P}$ !).

Fig. $2 b$

Subarbustos a arbustos monoicos, 0,5-2 $\mathrm{m}$ alt.; com ramificação filantoide, caule liso, ramos cilíndricos, glabros. Folhas membranáceas, levemente discolores, 15-39 × 5-16 mm; ovais; ápice acuminado a longo-acuminado; base aguda a arredondada; faces adaxial e abaxial glabras; margem revoluta; nervação broquidodróma; pecíolos 1-2 mm compr.; estípulas $2-5 \mathrm{~mm}$ compr., estreitamente triangulares, glabras. Inflorescências em címulas axilares, compostas por 2-3 flores, às vezes flores solitárias; brácteas $0,5-1 \mathrm{~mm}$ compr., estreitamente triangulares. Flores masculinas 1,5-2 mm compr.; sépalas 5, 1-2 mm compr., 


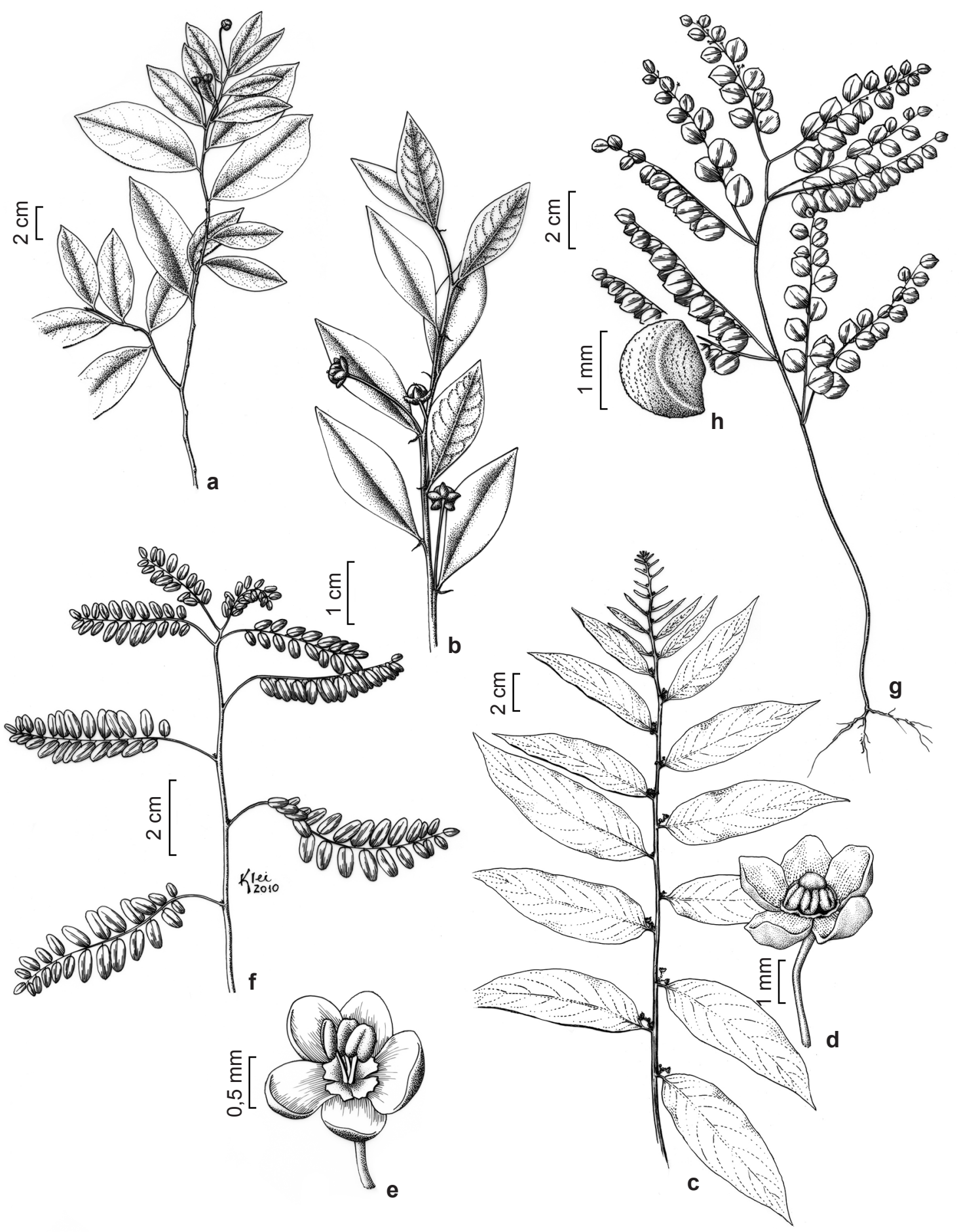

Figura 2 - a. Phyllanthus cladotrichus - ramo. b. Phyllanthus glaziovii - ramo evidenciando forma das folhas. c-d. Phyllanthus juglandifolius - c. ramo; d. flor masculina. e-f. Phyllanthus niruri - e. flor masculina; f. ramo. g-h. Phyllanthus orbiculatus - g. hábito; h. semente. (a M. Kuhlmann 3860; b M. Kuhlmann 3195; c-d E.R. Martins 32; e G. Hashimoto 18814; f R. Kral 75691; g M. Sugiyama 89; h L.R. H. Bicudo 449).

Figure 2 - a. Phyllanthus cladotrichus - branch. b. Phyllanthus glaziovii-branch showing leaf shape. c-d. Phyllanthus juglandifolius -c. branch; d. male flower. e-f. Phyllanthus niruri - e. male flower; f. branch. g-h. Phyllanthus orbiculatus - g. habit; h. seed. (a M. Kuhlmann 3860; b M. Kuhlmann 3195; c-d E.R. Martins 32; e G. Hashimoto 18814; f R. Kral 75691; g M. Sugiyama 89; h L.R.H. Bicudo 449). 
elípticas a ovais, membranáceas; estames 3 , filetes completamente livres, anteras com deiscência vertical; disco 5-lobado; pedicelo 7-8 mm compr. Flores femininas 2-5 mm compr.; sépalas 5, 2-5 mm compr., elípticas a ovais, membranáceas; ovário ca. $1 \mathrm{~mm}$ compr., estiletes 3, 2-fidos até a metade; disco inteiro; pedicelo 7-18 $\mathrm{mm}$ compr. Cápsulas 4-5 × 4-6 mm. Sementes 1,5-2 mm compr., castanho-amareladas, verruculosas.

Material selecionado: Guapimirim, VIII.1993, fl. e fr., J.M.A. Braga 529 (RB).

Phyllanthus glaziovii caracteriza-se pela margem revoluta, ápice acuminado a longoacuminado, nervuras terciárias vináceas, bem evidentes e densamente reticuladas, enquanto que nas demais espécies do Rio de Janeiro as mesmas são inconspícuas; os pedicelos de ambas as flores relativamente longos quando comparados ao das demais espécies de Phyllanthus, sendo, geralmente, três vezes maiores do que as flores. O ovário fica quase totalmente imerso no disco das flores femininas, que é bastante desenvolvido.

Espécie exclusiva do Brasil, onde pode ser encontrada nas Regiões Sudeste (Minas Gerais, São Paulo e Rio de Janeiro) e Sul (Paraná), em floresta ombrófila densa atlântica alto-montana (Secco et al. 2013). Coletada com flores e frutos nos meses de janeiro, março, abril e de agosto a outubro. Seu status de conservação é pouco preocupante (LC) já que possui um número significativo de coletas, sendo algumas delas recentes em áreas de proteção, como o Parque Nacional de Itatiaia.

10. Phyllanthus itatiaiensis Brade, Arch. Jard. Bot. Rio de Janeiro 15: 9. 1957. Tipo: BRASIL. RIO DE JANEIRO: Itatiaia, Pedra do Altar. 1937/3, A.C. Brade 15575. (holótipo RB!; isótipos NY n.v., fotografia do isótipo em $\mathrm{F}$ !).

Ervas monoicas, ca. 0,2 m alt.; sem ramificação filantoide, caule liso, ramos cilíndricos, glabro. Folhas membranáceas, discolores, 2-4 $\times$ 1,5-3 mm; falcadas; ápice obtuso; base obtusa; faces adaxial a abaxial glabras; margem levemente revoluta; nervação cladodróma; pecíolos ca. 0,5 mm compr.; estípulas 1-1,5 mm compr., triangular-lanceoladas, glabras. Inflorescências em címulas axilares, compostas geralmente por flores solitárias; brácteas 1-1,5 mm compr., triangularlanceoladas. Flores masculinas 2-2,5 mm compr.; sépalas 5, 1-1,5 mm compr., ovais a elípticas, membranáceas; estames 3 , filetes completamente livres, anteras com deiscência horizontal; disco 5-segmentado; pedicelo 1-2 mm compr. Flores femininas 1-1,5 mm compr.; sépalas 5, ca. $1 \mathrm{~mm}$ compr., elípticas, membranáceas; ovário ca. 0,5 mm compr., estiletes 3, 2-fidos apenas no ápice; disco inteiro; pedicelo ca. $1 \mathrm{~mm}$ compr. Cápsulas não observadas. Sementes não observadas.

Material selecionado: Itatiaia V.1950, fl., A.C. Brade 20362 (RB).

Phyllanthus itatiaiensis é muito semelhante a $P$. niruri, devido ao habito herbáceo, as flores masculinas e femininas com cinco sépalas e o androceu formado por três estames com filetes livres, caracteres esses comuns às duas espécies. Porém distingue-se por suas folhas falcadas, com margem levemente revoluta e pelos pedicelos das flores masculinas que variam de 1 a 2 mm de comprimento, enquanto em $P$. niruri as folhas são oblongas, com margem plana e os pedicelos das flores masculinas variam de 2,5 a $4 \mathrm{~mm}$ de comprimento.

Phyllanthus itatiaiensis é um táxon encontrado exclusivamente no Brasil, endêmico do estado do Rio de Janeiro, onde ocorre apenas no Maciço do Itatiaia, mais precisamente na Pedra do Altar. Segundo informações de Brade na descrição original, ocorre sempre associada a Chusquea pinifolia Nées, em áreas cuja elevação varia dos 2400 aos 2600 metros. Coletada com flores apenas no mês de março. Seu status de conservação é ameaçado (EN), já que apresenta poucas coletas sempre na mesma região.

11. Phyllanthus juglandifolius Willd., Enum. Hort. Berol. Suppl. 64-65. 1813. Tipo: PORTO RICO. C.L.G. Bertero s.n. (holótipo P n.v., fotografia do holótipo em P! (P00608985)). $\quad$ Fig. 2c-d

Arbustos a arvoretas monoicas, 2,5-5 m alt.; com ramificação filantoide, caule liso, ramos cilíndricos, achatados na porção terminal, glabros a pubescentes. Folhas membranáceas, discolores, 51-132 × 15-51 mm; elípticas a ovais; ápice cuspidado a acuminado; base atenuada a cordada, faces adaxial e abaxial pubescentes; margem plana; nervação eucamptódroma; pecíolos 3-4 mm compr., pubescentes; estípulas 1-1,5 mm compr., estreitamente triangulares, pubescentes. Inflorescências em címulas axilares, compostas por flores solitárias; brácteas 1-1,5 mm compr., estreitamente triangulares. Flores masculinas 1-1,5 mm compr.; sépalas 5, 1-1,5 mm compr., circulares, membranáceas; estames 4-6, filetes completamente unidos formando uma coluna, anteras com deiscência vertical; disco inteiro; pedicelo 12-15 mm compr. 
Flores femininas 1-1,5 mm compr.; sépalas 5, 1-1,5 $\mathrm{mm}$ compr., elípticas, circulares, membranáceas; ovário ca. 0,5 mm compr., estiletes 3, 2-fidos apenas no ápice; disco inteiro; pedicelo $13-18 \mathrm{~mm}$ compr. Cápsulas ca. $7 \times 11 \mathrm{~mm}$. Sementes 3-4 mm compr., castanhas, verruculosas.

Nomes populares: cajazeira-braba, carobinha (Silva \& Sales 2007).

Material selecionado: Nova Iguaçu, XI.2001, fl., S.J. Silva Neto 1526 (RB).

Phyllanthus juglandifolius distingue-se das outras espécies de Phyllanthus do Rio de Janeiro por seu hábito arbustivo a arvoretas, que pode alcançar até $5 \mathrm{~m}$ de altura e principalmente pelo androceu formado por quatro a seis estames com filetes completamente unidos, formando uma coluna. Apesar de P. acuminatus, P. cladotrichus e $P$. riedelianus também possuirem porte arbustivo, chegando a até nove, sete e $15 \mathrm{~m}$ de altura, respectivamente, o número de estames pode auxiliar na distinção destes táxons, já que em $P$. acuminatus e P. riedelianus o androceu é formado por três estames com filetes completamente unidos e em P. cladotrichus o androceu possui apenas dois estames com filetes completamente unidos, formando uma coluna.

Espécie encontrada nas porções norte e sul da América do Sul, na Bolívia, Brasil, Equador, Guiana Francesa, Peru, Trindade e Tobago e Venezuela (Webster 1956; Gillespie 1993). No Brasil, ocorre nas Regiões Norte (Pará, Amazonas, Tocantins e Rondônia), Nordeste (Bahia) e Sudeste (Minas Gerais, São Paulo, Rio de Janeiro), em floresta ombrófila densa atlântica de encosta e floresta estacional (Secco et al. 2013). Coletada com flores de setembro a novembro e em janeiro e com frutos de janeiro a março, junho, setembro e outubro. Phyllanthus juglandifolius apresenta status de conservação pouco preocupante (LC) por ser uma espécie de ampla distribuição, que possui um número significativo de coletas recentes.

12. Phyllanthus mocotensis G.L.Webster, Lundellia 5: 14. 2002. Tipo: BRASIL. RIO DE JANEIRO: Alto Mocotó, 1933, S. Lima 194 (holótipo RB!).

Ervas monoicas, com ramificação filantoide, caule liso, ramos cilíndricos, glabros. Folhas membranáceas, levemente discolores, 4-6 6 2-4 $\mathrm{mm}$; oblonga a obovais; ápice obtuso apiculado; base cuneada; faces adaxial e abaxial pubescentes; margem revoluta; nervação broquidodróma; pecíolos ca. $1 \mathrm{~mm}$ compr.; estípulas 1,5-2 $\mathrm{mm}$ compr., estreitamente triangulares, glabras. Inflorescências em címulas axilares, compostas por 2-3 flores ou, às vezes, flores solitárias; brácteas 1,5-2 mm compr., estreitamente triangulares. Flores masculinas 1,5-2 $\mathrm{mm}$ compr.; sépalas 5, 1,5-2 mm compr., obovais, membranáceas; estames 3, filetes completamente livres, anteras com deiscência vertical, disco 5-lobado; pedicelo 2-3 mm compr. Flores femininas 1,5-2 mm compr.; pedicelo 4-5 mm compr ; sépalas 5, 1,5-2 mm compr., obovais; ovário ca. $0,5 \mathrm{~mm}$ compr., estiletes 3, 2-fidos até a metade; disco inteiro; pedicelo ca. $5 \mathrm{~mm}$ compr. Cápsulas não observadas. Sementes não observadas.

Material selecionado: Rio de Janeiro, Alto Mocotó, X.1933, fl., S. Lima, 194 (RB).

Conhecida apenas pela coleção-tipo, $P$. mocotensis é semelhante à $P$. itatiaiensis, da qual se distingue pelas folhas que variam de oblongas a obovais, pelos pedicelo das flores femininas que possuem cerca de $5 \mathrm{~mm}$ de comprimento, enquanto em $P$. itatiaiensis as folhas são falcadas, os pedicelos das flores femininas possuem até no máximo $1 \mathrm{~mm}$ de comprimento.

Táxon endêmico do Brasil, onde ocorre apenas na Região Sudeste, no estado do Rio de Janeiro em floresta ombrófila densa atlântica. Coletada com flores e frutos apenas no mês de outubro. Seu status de conservação é ameaçado (EN). Phyllanthus mocotensis é conhecida apenas pelo material-tipo.

13. Phyllanthus niruri L., Sp. Pl. 2: 981. 1753. Tipo: Hortus Cliffortianus 440, C. Linnaeus Phyllanthus n. 2 (lectótipo BM n.v., fotografia do lectótipo em BM!). Phyllanthus lathyroides var. lathyroides for. rosellus Müll. Arg. Linnaea 32:42. 1863, Phyllanthus rosellus (Müll. Arg.) Müll. Arg. Fl. Bras. 11(2): 53. 1873. Tipo: Ouro Preto, Vauthier 83 (lectótipo W n.v.). $\quad$ Fig. 2e-f

Ervas monoicas, 0,5-2 malt.; com ramificações filantoide, caule liso, ramos cilíndricos, glabros. Folhas membranáceas, levemente discolores, $2-12(-19) \times 1,5-6(-10) \mathrm{mm}$; oblongas; ápice arredondado, apiculado; base assimétrica a cordada; faces adaxial e abaxial glabras; margem plana; nervação cladodróma; pecíolos $1-1,5 \mathrm{~mm}$ compr; estípulas 1-2 mm compr., estreitamente triangulares a lineares, glabras. Inflorescências em címulas axilares, compostas, geralmente, por flores solitárias; brácteas 1-4 mm compr., lineares. 
Flores masculinas 2-3 mm compr.; sépalas 5, 1,5-2 mm compr., obovais a largamente obovais, membranáceas; estames 3 , filetes completamente livres, anteras com deiscência horizontal; disco 5-segmentado; pedicelo 2,5-4 mm compr. Flores femininas 2,5-3 mm compr.; sépalas 5, 2-3 $\mathrm{mm}$ compr., obovais a largamente obovais, membranáceas; ovário ca. $0,5 \mathrm{~mm}$ compr., estiletes 3, 2-fidos até a metade; disco inteiro; pedicelo 2-5 $\mathrm{mm}$ compr. Cápsulas ca. $2 \times 3 \mathrm{~mm}$. Sementes $1-1,5$ mm compr., castanhas, verruculosas.

Nomes populares: quebra-pedra, ervapombinha (Silva \& Sales 2007).

Material selecionado: Paraty, III.2003, fl. e fr., $D$. Mello 22 (R).

Phyllanthus niruri é a espécie mais conhecida e estudada do gênero, devido às suas propriedades medicinais, que a tornaram muito utilizada como diurético na medicina popular, para tratamento de pedras nos rins. Pode ser facilmente confundida com outras espécies que ocorrem no estado do Rio de Janeiro, tais como $P$. amarus, $P$. caroliniensis, $P$. tenellus e $P$. urinaria. Distingue-se facilmente de $P$. caroliniensis e $P$. urinaria por possuir cinco sépalas em ambas as flores, enquanto estas possuem seis. Das outras duas espécies, que também possuem flores com cinco sépalas, distingue-se pelo androceu, com três estames livres, enquanto em $P$. tenellus há cinco estames também livres e em P. amarus dois com filetes completamente unidos. Além disso, foi observado papilas nos segmentos do disco das flores masculinas.

Allem (1977) reduziu Phyllanthus rosellus (Müll. Arg.) Müll. Arg. a um sinônimo de Phyllanthus niruri L. Porém Webster (2002a) com base no tamanho das folhas, pedicelos das flores masculinas e coloração das sépalas (folhas 7-17 mm, sépalas amareladas a esverdeadas e pedicelo masculino $1-3 \mathrm{~mm}$ em $P$. niruri $\times$ folhas 3-5 (-8) mm, sépalas avermelhadas e pedicelo masculino 4-6 $\mathrm{mm}$ em $P$. rosellus) restabeleceu $P$. rosellus como uma espécie distinta de $P$. niruri. O exame de coleções e observação de populações no campo, nos levou a concordar com Allem (1977), pois foram encontrados indivíduos com medidas intermediárias de limbo e pedicelo e flores esverdeadas ou avermelhadas que interpretamos como variações de uma única espécie.

Este táxon apresenta distribuição em todo o território americano, ocorrendo desde os Estados Unidos até a Argentina, incluindo Antilhas (Webster 1970). No Brasil, pode ser encontrada nas
Regiões Norte (Roraima, Amapá, Pará, Amazonas, Tocantins, Acre e Rondônia), Nordeste (Maranhão, Ceará, Rio Grande do Norte, Paraíba, Pernambuco, Bahia, Alagoas e Sergipe), Centro-Oeste (Mato Grosso, Goiás, Distrito Federal e Mato Grosso do Sul), Sudeste (Minas Gerais, Espírito Santo, São Paulo e Rio de Janeiro) e Sul (Paraná, Santa Catarina e Rio Grande do Sul), onde ocorre em campo cerrado, campo rupestre, borda de floresta ombrófila densa e de floresta ombrófila mista, além de ocorrer também como planta ruderal em culturas ou terrenos abandonados (Secco et al. 2013). Coletada com flores e frutos em todos os meses do ano. Seu status de conservação é pouco preocupante (LC) já que apresenta ampla distribuição, possui um número significativo de coletas, sendo varias recentes.

14. Phyllanthus orbiculatus L.C. Rich., Act. Soc. Hist. Nat. Paris 1: 113. 1792. Tipo: GUIANA FRANCESA. Cayenne: Leblond s.n. (holótipo P n.v., fotografia do holótipo em P! (P00609701)).

Fig. 2g-h

Ervas monoicas, 0,1-1,5 m alt.; com ramificação filantoide, caule liso, ramos cilíndricos, achatados na porção terminal. Folhas membranáceas, levemente discolores, 3-9 × 3-9 mm; orbiculares a largamente ovais; ápice cuspidado a obtuso; base arredondada; face adaxial glabra a pubescente; face abaxial glabra; margem plana; nervação cladodróma; pecíolos 1-1,5 mm compr.; estípulas ca. $1 \mathrm{~mm}$ compr., lanceoladas, glabras. Inflorescências em címulas axilares, compostas geralmente por 2 flores; brácteas ca. $1 \mathrm{~mm}$ compr., lanceoladas. Flores masculinas 1,5-2,5 mm compr.; sépalas 6, 1-1,5 mm compr., elípticas, membranáceas, vináceas; estames 3 , filetes completamente livres, anteras com deiscência horizontal; disco 6-lobado; pedicelo 1,5-3 mm compr. Flores femininas 0,5-1 $\mathrm{mm}$ compr.; sépalas 6, ca. $1 \mathrm{~mm}$ compr., estreitamente elípticas, membranáceas, vináceas; ovário ca. 0,5 mm compr., estiletes 3, 2-fidos até a metade; disco 6-lobado; pedicelo 1,5-9 mm compr. Cápsulas ca. $2 \times 2 \mathrm{~mm}$. Sementes 1-2 mm compr., castanhoamareladas, verruculosas.

Material selecionado: Rio de Janeiro, IX.1978, fl., P.P. Jouvin, 227 (RB).

Esta espécie, como o próprio epíteto sugere, possui folhas arredondadas, geralmente avermelhadas ou vináceas, com a face adaxial coberta por tricomas alvos, especialmente sobre as nervuras e na linha mediana das sépalas. Phyllanthus orbiculatus pode 
ser confundida com $P$. subemarginatus por conta da forma das folhas e do androceu formado por três estames com filetes livres, mas o número de sépalas de ambas as flores, sua coloração e a morfologia do disco das flores femininas (6-lobado na primeira, e inteiro na segunda) auxiliam na distinção entre essas duas espécies.

Phyllanthus orbiculatus apresenta distribuição sul-americana, sendo encontrada no Brasil, Bolívia, Paraguai, Colômbia, Venezuela, Guianas, Peru e Trindade e Tobago (Gillespie 1993; Silva \& Sales 2007; Webster 1956). No Brasil, ocorre nas Regiões Norte (Amapá, Pará, Amazonas e Rondônia), Nordeste (Bahia), Centro-Oeste (Goiás e Mato Grosso do Sul), Sudeste (Minas Gerais e São Paulo) e Sul (Paraná), de acordo com Webster (1957), floresta ombrófila densa amazônica e atlântica, Cerrado e em áreas de borda de floresta estacional semidecidual. Coletada com flores e frutos de janeiro a julho e de outubro a novembro. Phyllanthus orbiculatus apresenta status de conservação pouco preocupante (LC) por ser uma espécie de ampla distribuição, que possui um número significativo de coletas, sendo algumas delas recentes, além de ocorrer em áreas de conservação, como o Parque Nacional da Serra do Cipó.

15. Phyllanthus riedelianus Müll. Arg., Linnaea 32: 16. 1863. Tipo: BRASIL. L. Riedel 1621 (isótipo NY n.v., fotografia do isótipo em NY!).

Fig. 3a

Árvoretas monoicas, 3-15 m alt.; sem ramificação filantoide, caule liso, ramos cilíndricos, achatados na porção terminal, glabros. Folhas subcoriáceas, discolores, 39-64 × 7-16 mm; elípticas a ovais; ápice acuminado a cuspidado; base aguda a atenuada; faces adaxial e abaxial glabras; margem revoluta; nervação eucamptódroma; pecíolos 2-3 mm compr.; estípulas 1-2 mm compr., estreitamente triangulares, glabras. Inflorescência em címulas axilares, compostas por mais de 6 flores; brácteas ca. 0,5 mm compr., estreitamente triangulares. Flores masculinas 0,5-1 $\mathrm{mm}$ compr.; sépalas 6, 0,5-1 mm compr., elípticas, membranáceas; estames 3 , filetes completamente unidos formando uma coluna, anteras com deiscência vertical; disco 6-lobado; pedicelo 2,5-4 mm compr. Flores femininas não observadas. Cápsulas 6-7 × $8 \mathrm{~mm}$. Sementes 3-3,5 mm compr., amareladas, lisas.

Material selecionado: Cabo Frio, IX.1979, fl., G. Martinelli 6132 (RB)
Phyllanthus riedelianus pode ser confundida com P. cladotrichus e P. juglandifolius, pois essas três espécies variam de arbustos a pequenas árvores e possuem folhas variando de elípticas a ovais. Porém, distingue-se dessas pelo número de sépalas das flores masculinas (cinco em P. cladotrichus e $P$. juglandifolius e seis em P. riedelianus) e pelo androceu, já que em $P$. cladotrichus o androceu é formado por quatro estames com filetes unidos em dois pares, em $P$. riedelianus por três estames com filetes completamente unidos e em P. juglandifolius, os estames, apesar de também apresentarem filetes completamente unidos, variam de quatro a seis.

Táxon endêmico do Brasil, onde ocorre nas Regiões Sudeste (Minas Gerais, São Paulo e Rio de Janeiro) e Sul (Paraná e Santa Catarina), em floresta ombrófila densa atlântica, sempre em borda de matas ciliares e, às vezes, como planta ruderal, crescendo em áreas de pastagem (Secco et al. 2013). Coletada com flores nos meses de setembro e dezembro e com frutos nos meses de fevereiro e dezembro. Seu status de conservação é pouco preocupante (LC) apesar de não ocorrer em áreas de conservação apresentar ampla distribuição com um número significativo de coletas recentes.

16. Phyllanthus rosmarinifolius Müll. Arg., Fl. bras. 11(2): 60. 1873. Tipo: BRASIL. RIO DE JANEIRO: Serra dos Órgãos, G. Gardner 5852 (holótipo G n.v., referido por Webster (2002a)).

Fig. 3b-c

Ervas monoicas, ca. $0,3 \mathrm{~m}$ alt.; sem ramificação filantoide, caule liso, ramos cilíndricos, achatados na porção terminal, glabros. Folhas coriáceas, discolores, 6-14 × 0,5-2,5 mm; lineares; ápice retuso; base aguda a retusa; face adaxial glabra, face abaxial pubescente; margem revoluta; nervação uninérvea; pecíolos ca. $1 \mathrm{~mm}$ compr.; estípulas 1-1,5 mm compr., estreitamente triangulares, glabras. Címulas axilares, compostas por flores solitárias; brácteas 1,5-2 mm compr., estreitamente triangulares. Flores masculinas 1,5-2 mm compr.; sépalas 5, 1,5-2 mm compr., obovais, membranáceas; estames 3 , filetes completamente livres, anteras com deiscência horizontal; disco 5-lobado; pedicelo ca. 0,5 mm compr. Flores femininas não observadas. Cápsulas não observadas. Sementes não observadas.

Material selecionado: Teresópolis, VI.1951, fl., C.T. Rizzini 671 (RB).

Phyllanthus rosmarinifolius é uma espécie bem diferente das demais ocorrentes no estado 

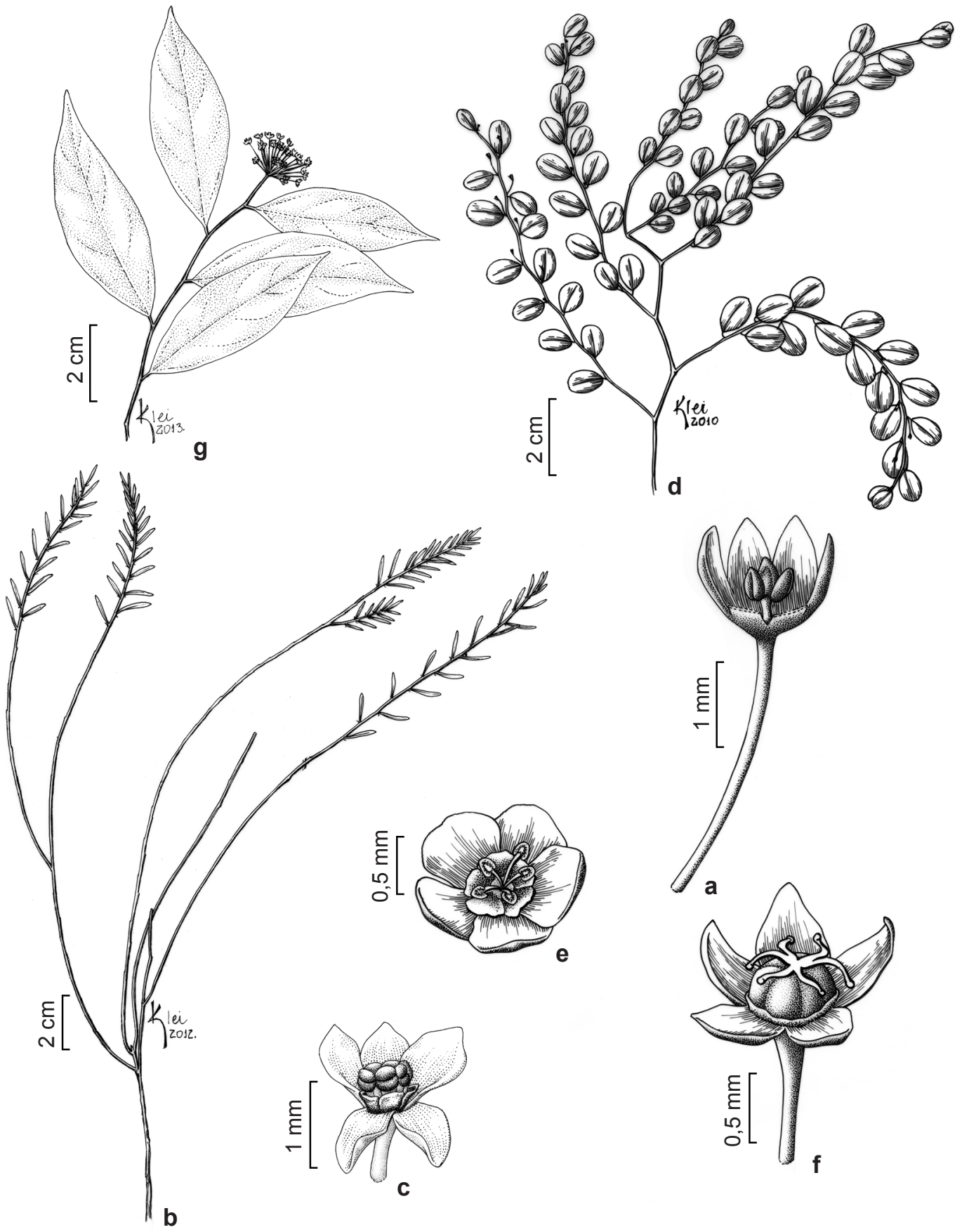

Figura 3 - a. Phyllanthus riedelianus - flor masculina. b-c. Phyllanthus rosmarinifolius - b. ramo evidenciando forma das folhas; c. flor masculina. d. Phyllanthus subemarginatus - ramo evidenciando forma das folhas. e-f. Phyllanthus tenellus - e. flor masculina; f. flor feminina. g. Phyllanthus umbratus - ramo evidenciando a inflorescência terminal. (a M. Kuhlmann 2562; b-c J.H. Kirkbride 1719; d M.P. Costa 38; e M.A. Pregun 1; f O. Scavone (SP385027); g H.C. Lima 2576).

Figure 3 - a. Phyllanthus riedelianus - male flower. b-c. Phyllanthus rosmarinifolius - b. branch showing leaf shape; c. male flower. d. Phyllanthus subemarginatus - branch showing leaf shape. e-f. Phyllanthus tenellus - e. male flower; f. female flower. g. Phyllanthus umbratus - branch showing the terminal inflorescence. (a M. Kuhlmann 2562; b-c J.H. Kirkbride 1719; d M.P. Costa 38; e M.A. Pregun 1; f O. Scavone (SP385027); g H.C. Lima 2576). 
do Rio de Janeiro, já que o formato das folhas lineares, com textura coriácea e margens revolutas a distingue facilmente das outras espécies.

Endêmica do Brasil e exclusiva da Região Sudeste, onde ocorre apenas no estado do Rio de Janeiro, em floresta ombrófila densa atlântica, nos campos de altitudes. Coletada com flores nos meses de abril e junho. O status de conservação de Phyllanthus rosmarinifolius é de ameaçada (EN), já que é uma espécie endêmica do estado do Rio de Janeiro com poucas coletas e nenhuma em área de conservação.

17. Phyllanthus subemarginatus Müll. Arg., Linnaea 32(4): 39. 1863. Tipo: BRASIL. RIO DE JANEIRO: Vauthier 84 (lectótipo W n.v., referido por Webster [2002b]). Phyllanthus janeirensis Müll. Arg., Fl. bras. 11(2): 45. 1873. Tipo: BRASIL, RIO DE JANEIRO: A.F.M. Glaziou 1467 (holótipo G n.v.). Phyllanthus retroflexus Brade, Arch. Jard. Bot. Rio de Janeiro 15: 8, t.1 (figs 9-11), 6. 1957. Tipo: BRASIL. ESPÍRITO SANTO: Cachoeira do Tapemirim, Vargem Alta, Morro de Sal, 700m, IV.1949, Brade 19768 (holótipo RB!). Fig. 3d

Ervas monoicas, 0,5-1,5 m alt.; sem ramificação filantoide, caule liso, ramos longos e delgados, cilíndricos, glabros. Folhas membranáceas, levemente discolores, 4-25 × 3-19 mm; orbiculares; ápice arredondado, apiculado; base arredondada; faces adaxial e abaxial glabras; margem revoluta; nervação broquidodróma; pecíolos 1,5-2 $\mathrm{mm}$ compr.; estípulas ca. $0,5 \mathrm{~mm}$ compr., triangulares, glabras. Inflorescências em címulas axilares, compostas por 3 flores ou, às vezes, flores solitárias; brácteas ca. $0,5 \mathrm{~mm}$ compr., triangulares. Flores masculinas 1,5-2 mm compr.; sépalas $5,1-1,5 \mathrm{~mm}$ compr., obovais, membranáceas; estames 3 , filetes completamente livres, anteras com deiscência vertical; disco 5-lobado; pedicelo 2,5-3 mm compr. Flores femininas 1,5-2 mm compr.; sépalas 5, 1-2 mm compr., obovais, membranáceas; ovário ca. 0,5 mm compr., estiletes 3, 2-fidos apenas no ápice; disco inteiro; pedicelo 3-5(-6) $\mathrm{mm}$ compr. Cápsulas ca. $2 \times 2,5 \mathrm{~mm}$. Sementes ca. $1 \mathrm{~mm}$ compr., castanhas, verruculosas.

Material selecionado: Parati, $23^{\circ} 13^{\prime} \mathrm{S}$ e $44^{\circ} 42-43^{\prime} \mathrm{W}$, IV.1965, fl., G. Eiten \& L.T. Eiten 6261 (SP).

Phyllanthus subemarginatus apresenta folhas com nervação broquidódroma e ramos longos e delgados que podem ser utilizados no reconhecimento dessa espécie. Segundo Webster (1959), as plantas de Santa Catarina apresentam os pedicelos das flores femininas duas vezes mais longos do que os dos indivíduos coletados em outros estados do país, variando de 8 a $10 \mathrm{~mm}$ de comprimento. Phyllanthus subemarginatus é muito semelhante à $P$. orbiculatus, pois ambas apresentam folhas orbiculares e hábito herbáceo. Porém, em $P$. subemarginatus ambas as flores possuem cinco sépalas e o disco das flores femininas é inteiro, ao passo que em $P$. orbiculatus ambas as flores possuem seis sépalas e o disco das flores femininas 6-lobado.

Silva \& Sales (2008) propuseram o restabelecimento de Phyllanthus retroflexus, sinonimizado em P. subermaginatus por Webster (2002a). Entretanto, após análise cuidadosa de coleções provenientes do estado do Rio de Janeiro e também da coleção-tipo de $P$. retroflexus, considerando as características diagnósticas utilizadas por Silva \& Sales (2008) para diferenciar estas espécies, como folhas cartáceas, variando de ovadas a arredondadas, com margem fortemente revoluta e sépalas das flores masculinas com uma marca avermelhada na região central em $P$. retroflexus, enquanto em $P$. subemarginatus as folhas seriam membranáceas, largamente elípticas, com margens planas, não foi possível distinguir estas duas espécies. Portanto, neste trabalho optamos por aceitar a sinonimização de $P$. retroflexus em $P$. subermaginatus proposta por Webster (2002a).

Em estudos sobre o gênero Phyllanthus no Brasil, Webster (2002b) reconheceu $P$. subemarginatus e $P$. claussenii, e comentou sobre algumas características distintivas entre eles, bem como a confusão na identificação de coleções dessas duas espécies nos herbários. Silva \& Sales (2008) também reconheceram estas duas espécies, aparentemente com base no número de sépalas das flores. Na Tabela 1 estão indicadas as principais características que levaram Müller (1873), Webster (2002a) e Silva \& Sales (2008) a reconhecerem $P$. subemarginatus e $P$. claussenii como espécies distintas.

Depois da análise de 375 coleções provenientes da Região Sudeste do Brasil, com características intermediárias entre as contidas nas diagnoses dessas duas espécies, bem como nos referidos trabalhos, concluímos tratar-se de um único táxon, com cinco a seis sépalas, que variam entre 0,8 e $1,5 \mathrm{~cm}$ de comprimento, pedicelos do fruto variando entre 2 e $18 \mathrm{~mm}$ de comprimento e sementes variando entre 1 e 1,5 mm de comprimento. Essa posição justifica-se, primeiramente, por não encontrarmos nenhuma coleção com um único 
Tabela 1 - Diferenças apresentadas por diferentes autores utilizadas na distinção entre Phyllanthus subemarginatus e P. claussenii.

Table 1 - Differences presented by different authors used to the distinction between Phyllanthus subemarginatus and P. claussenii.

\begin{tabular}{|c|c|c|c|}
\hline Espécie & Müller (1863) & Webster (2002a) & Silva \& Sales (2008) \\
\hline Phyllanthus subemarginatus & $\begin{array}{l}\text { Espécie dióica, glândulas do disco da } \\
\text { flor masculina livres, cuneadas; sementes } \\
\text { com testa irregularmente, pontuada }\end{array}$ & $\begin{array}{l}\text { Espécie dioica; sépalas na maioria } \\
5 \text {, variando de } 1-1,5 \mathrm{~mm} \text { compr.; } \\
\text { pedicelo dos frutos } 2-5 \mathrm{~mm} \\
\text { compr.; sementes } 1-1,2 \mathrm{~mm}\end{array}$ & Flores com 5 sépalas \\
\hline Phyllanthus claussenii & $\begin{array}{l}\text { Espécie monóica, glândulas do disco da } \\
\text { flor masculina subturbinadas, papilosas }\end{array}$ & $\begin{array}{l}\text { Espécie monoica; sépalas na } \\
\text { maioria } 6 \text {, variando de } 0,8-1 \mathrm{~mm} \\
\text { compr.; pedicelo dos frutos } 7-18 \\
\text { mm compr.; sementes } 1,3-1,4 \mathrm{~mm}\end{array}$ & Flores com 6 sépalas \\
\hline
\end{tabular}

tipo de flor, indicando uma possível dioicia, característica inclusive bastante rara nas espécies brasileiras do gênero. Em segundo lugar, também não foi possível associar claramente flores com cinco ou seis sépalas com as diferentes medidas de sépalas, pedicelo dos frutos e sementes, como apresentado por Webster (2002a). Vale ressaltar que apesar de Müller (1863) não mencionar o número de sépalas na diagnose de $P$. claussenii, na prancha da espécie na Flora brasiliensis Müller (1873) tanto a flor masculina como a feminina possuem cinco sépalas.

Das 11 coleções citadas por Webster (2002b) como Phyllanthus claussenii, seis foram aqui analisadas, tratando-se uma delas (Pickel 360 SPSF), de P. orbiculatus. Das 13 coleções citadas no mesmo trabalho como $P$. subemarginatus, oito foram aqui examinadas.

Apesar de acreditarmos que Phyllanthus claussenii poderia ser sinonimizado sob $P$. subemarginatus, preferimos não fazê-lo aqui formalmente, uma vez que não tivemos acesso ao lectótipo de $P$. claussenii, a coleção Claussen 1530 depositada no herbário do Museu de História Natural de Viena (W).

Espécie endêmica do Brasil encontrada no Nordeste (Ceará, Pernambuco e Bahia), Sudeste (Minas Gerais, Espírito Santo, São Paulo e Rio de Janeiro) e Sul (Paraná e Santa Catarina), crescendo, principalmente, na porção leste do país (Silva \& Sales 2008). Encontrada na floresta ombrófila densa atlântica e Cerrado, nas matas ciliares, junto a formações rochosas. Coletada com flor nos meses de janeiro a março (Webster 2002b) e em novembro. Seu status de conservação é pouco preocupante (LC) por ser uma espécie de ampla distribuição, que possui um número significativo de coletas, sendo varias recentes.
18. Phyllanthus tenellus Roxb., Fl. Ind. 2(3): 668. 1882. Tipo: INDIA. West Bengal Calcutta Botanical Garden, Wallich 7892 (holótipo K n.v., referido por Webster [2001]). $\quad$ Fig. 3e-f

Ervas monoicas, 0,1-1 m alt.; com ramificação filantoide, caule liso, ramos cilíndricos, achatados na porção terminal, glabros. Folhas membranáceas, levemente discolores, 5-15 × 3-8 mm; elípticas a obovais; ápice arredondado a obtuso; base aguda; face adaxial glabra a pubescente; face abaxial glabra; margem plana; nervação cladodróma; pecíolos $0,5-1 \mathrm{~mm}$ compr.; estípulas $1-2 \mathrm{~mm}$ compr., estreitamente triangulares, glabras. Inflorescências em címulas axilares, compostas, em geral, por 2 flores, ou, às vezes, flores solitárias; brácteas 1-2 mm compr., estreitamente triangulares. Flores masculinas 1-1,5 mm compr.; sépalas 5, 1-1,5 mm compr., obovais, membranáceas; estames 5(-6), filetes completamente livres, anteras com deiscência vertical; disco 5(-6)lobado; pedicelo $1-1,5 \mathrm{~mm}$. Flores femininas $0,5-1 \mathrm{~mm}$ compr.; sépalas 5, 0,5-1 mm, ovais a triangulares, membranáceas; ovário ca. $0,5 \mathrm{~mm}$ compr., estiletes 3, 2-fidos desde a base; disco inteiro, pouco desenvolvido; pedicelo 3-4 mm compr. Cápsulas 1-1,5 × 1,5-2 mm. Sementes 0,5-1 mm compr., castanho-amareladas, verruculosas.

Nomes populares: arrebenta-pedra, ervapombinha, quebra-pedra, quebra-pedra-roxo (Silva \& Sales 2007).

Material selecionado: Itatiaia, IV.1963, fl., C.Pereira \& E. Pereira $59(\mathrm{HB})$.

Em Phyllanthus tenellus a base das folhas é sempre aguda, as flores femininas possuem disco pouco desenvolvido, as masculinas possuem cinco ou raramente seis estames livres, ao passo que em $P$. niruri, a espécie que mais se assemelha a $P$. tenellus, as folhas apresentam base obtusa, 
variando de cordadas a assimétricas, o disco das flores femininas é bem desenvolvido e as flores masculinas possuem três estames.

De acordo com Webster (2001), P. tenellus ocorre no México, leste dos Estados Unidos, Antilhas e América do Sul. No Brasil ocorre nas Regiões Norte (Pará), Nordeste (Ceará, Pernambuco, Bahia e Alagoas), Centro-Oeste (Mato Grosso), Sudeste (Minas Gerais, São Paulo e Rio de Janeiro) e Sul (Paraná e Santa Catarina), em floresta ombrófila densa atlântica a amazônica, em campo, capoeira e como invasora de culturas (Secco et al. 2013). Coletada com flores e frutos em todos os meses do ano, com exceção de setembro. Phyllanthus tenellus apresenta status de conservação pouco preocupante (LC) por ser uma espécie de ampla distribuição, que possui um número significativo de coletas.

19. Phyllanthus umbratus Müll. Arg., Prodr. 15(2): 356. 1866. Tipo: BRASIL. L. Riedel, s.n (holótipo $\mathrm{B}$ n.v., fotografia do holótipo em F! (F0BN005041); isótipo NY n.v., fotografia do isótipo em NY!).

Fig. $3 g$

Arbustos a arvoretas monoicas, 2,5-6 m alt.; ramos cilíndricos, glabros, caule liso, sem ramificação filantoide. Folhas membranáceas, discolores, 40-112 × 12-41 mm; elípticas; ápice acuminado; base retusa; faces adaxial a abaxial glabras; margem plana; nervação broquidodróma; pecíolos 2,5-3 mm compr.; estípulas 1-1,5 mm compr., triangulares, glabras. Inflorescências umbeliformes, compostas por mais de 20 flores ou, às vezes, flores solitárias; brácteas 0,5-1 mm compr., triangulares. Flores masculinas 1,5-2 mm compr.; sépalas 5, 1-1,5 mm compr., ovais, membranáceas; estames 2, filetes completamente unidos formando uma coluna, anteras com deiscência horizontal; disco 5-segmentado; pedicelo 6-7 mm compr. Flores femininas 1,5-2 mm compr.; sépalas 6, 1-1,5 mm compr., ovais; ovário ca. 0,5 mm compr., estiletes 3, 2-fidos até a base; disco 6segmentado; pedicelo ca. $10 \mathrm{~mm}$ compr. Cápsulas ca. $4 \times 5 \mathrm{~mm}$. Sementes não observadas.

Material selecionado: Rio de Janeiro, III.1945, fl., $P$. Occhioni 172 (RB).

Phyllanthus umbratus é muito semelhante a $P$. riedelianus, já que ambas variam de arbustos a pequenas árvores, com folhas elípticas. Porém, em P. umbratus as inflorescências são umbeliformes, sempre dispostas nas axilas do ápice dos ramos e as flores masculinas possuem o androceu formado por dois estames, ao passo que em $P$. riedelianus as inflorescências são glomeruliformes, e ocorrem em todas as axilas do ramo e as flores masculinas possuem o androceu com três estames.

Espécie endêmica do Brasil onde é encontrada apenas na Região Sudeste (Minas Gerais, Rio de Janeiro), em floresta ombrófila densa atlântica de encosta (Secco et al. 2013). Coletada com flores nos meses de fevereiro a abril e frutos nos meses de maio e julho. Seu status de conservação é ameaçado (EN). Ocorrendo em apenas dois estados brasileiros é conhecida por poucas coletas de localidades distantes entre si

20. Phyllanthus urinaria L., Sp. Pl. 1: 982. 1753. Tipo: Herb. Hermann 1: 15; 2: 7; 3: 55; 4: 41, No. 332 (lectótipo BM n.v., fotografia do lectótipo em BM!).

Ervas monoicas, ca. 0,5 m alt., com ramificação filantoide, caule liso, ramos cilíndricos, glabros. Folhas membranáceas, levemente discolores, 10-14 × 3-4 mm; elípticas, oblongas a obovais; ápice arredondado; base assimétrica, cordata; faces adaxial e abaxial glabras a pubescentes; margem levemente revoluta; nervação cladodróma; pecíolos 0,5-1 mm compr.; estípulas 1-1,5 mm compr., triangulares, glabras. Inflorescências em címulas axilares, compostas, geralmente, por 2-3 flores; brácteas 1-4 mm compr., triangulares. Flores masculinas ca. 0,5 mm compr.; sépalas 6 , ca. 0,5 mm compr., elípticas a obovais, membranáceas; estames 3, filetes completamente unidos formando uma coluna, anteras com deiscência vertical; disco 6-lobado; pedicelo 0,5-1 mm compr. Flores femininas ca. 0,5 mm compr.; sépalas 6 , ca. $0,5 \mathrm{~mm}$ compr., lanceoladas, membranáceas; ovário ca. 0,5 mm compr., estiletes 3, 2-fidos até a metade; disco inteiro; pedicelo 1-1,5 mm compr. Cápsulas ca. $2 \times$ $3 \mathrm{~mm}$, ornamentadas. Sementes 1-1,5 mm compr., castanho-amareladas, verruculosas.

Material selecionado: Rio de Janeiro, II.1996, st., D.L. Campos 80 (R).

Única espécie do gênero que possui frutos ornamentados já que nas demais são lisos, entretanto, com exceção desta característica, é muito semelhante à Phyllanthus niruri e P. amarus. Phyllanthus urinaria, porém possui androceu formado por três estames com filetes unidos e seis sépalas em ambas as flores, enquanto $P$. niruri o androceu possui três estames com filetes livres e cinco sépalas em ambas as flores. Apesar de P. amarus também possuir estames com filetes unidos, como em $P$. urinaria, o número de sépalas das flores é diferente, ou seja, cinco na primeira e seis na segunda. 
Nas Américas é referida para as Antilhas, Guianas, Guatemala, Honduras, Panamá, Venezuela e Brasil (Webster 1956; Rossignol et al. 1987). No Brasil, ocorre nas Regiões Norte (Amapá, Pará, Amazonas e Acre), Nordeste (Pernambuco e Bahia), Centro-Oeste (Mato Grosso e Goiás), Sudeste (Minas Gerais, Espírito Santo, São Paulo e Rio de Janeiro) e Sul (Paraná, Santa Catarina e Rio Grande do Sul), em floresta ombrófila densa amazônica e atlântica e em áreas de Cerrado, bordas de mata e como invasora de culturas e jardins (Silva \& Sales 2007). Pode ser encontrada também nas bordas de florestas de restinga. Coletada com flores no mês de março e abril e com frutos em março. Seu status de conservação é pouco preocupante (LC) por ser uma espécie de ampla distribuição, que possuem um número significativo de coletas, sendo algumas delas recentes.

\section{Agradecimentos}

À Coordenação de Aperfeiçoamento de Pessoal de Nível Superior (CAPES), pela bolsa concedida por meio do projeto PROTAX. Ao Instituto de Botânica da Secretaria do Meio Ambiente do Estado de São Paulo e ao Centro de Ciências Agrárias da Universidade Federal de São Carlos, por todo apoio e estrutura concedidos para realização desse trabalho. Ao ilustrador Klei Rodrigo Souza, pela elaboração das ilustrações e da arte final.

\section{Referências}

Allem, A.C. 1977. Notas sistemáticas y nuevos sinónimos en Euphorbiaceae de América del Sur - VII. Revista Brasileira de Biologia 37: 483-497.

Chase, M.W.; Soltis, D.E.; Olmstead, R.G.; Morgan, D.; Les, D.H.; Mishler, B.D.; Duvall, M.R.; Price, R.A.; Hills, H.G.; Qiu, Y.L.; Kron, K.A.; Rettig., J.H.; Conti, E.; Palmer, J.D.; Manhart, J.R.; Sytsma, K.J.; Michaels, H.J.; Kress, W.J.; Karol., K.H.; Clarck, W.D.; Hedrén, M.; Gaut, B.S.; Jansen, R.K.; Kim, K.J.; Wimpee, C.F.; Smith, J.F.; Furnier, G.R.; Strauss, S.H.; Xiang, Q.Y.; Plunkett, G.M.; Soltis, P.S.; Swensen, S.M.; Willians, S.E.; Gadek, P.A.; Quinn, C.J.; Eguiarte, L.E.; Golenberg, E.; Learn, J.R.; Graham, S.W.; Barrett, S.C.H.; Dayanandan, S. \& Albert, V.A. 1993. Phylogenetics of seed plants: an analysis of nucleotide sequences from plastide gene rbcL. Annals of the Missouri Botanical Garden 80: 528-580.

Chase, M.W.; Zmartzty, S.; Lledó, M.D.; Wurdack K.J.; Swesen, S.M. \& Fay, M.F. 2002. When in doubt, put it in Flacourtiaceae: a molecular phylogenetic analysis based on plastid rbcL DNA sequences. Kew Bulletin 57: 141-181.

Gillespie, L.J. 1993. Euphorbiaceae of the Guianas: annotated species checklist and key to the genera. Brittonia 45: 56-94.
Govaerts, R.; Frodin, D.G. \& Radcliffe-Smith, A. 2000. World checklist and bibliography of Euphorbiaceae (and Pandaceae) 4. Royal Botanic Gardens, Kew. Pp. 1257-1355.

Governo do Estado do Rio de Janeiro. 2013. O estado. Geografia. Disponível em $<$ http//www.rj.gov.br $>$. Acesso em 29 Mar 2013.

Hofmann, P.; Kathriarachchi, H. \& Wurdack, K.J. 2006. A phylogenetic classification of Phyllanthaceae (Malpighiales; Euphorbiaceae sensu lato). Kew Bulletin 61: 37-53.

IBGE - Instituto Brasileiro de Geografia e Estatística. 2013. Estados. Disponível em $<$ http//www.ibge.org. br>. Acesso em 29 Mar 2013.

IUCN. 2011. IUCN Red List of Threatened Species. Version 2011.1. Disponível em <www.iucnredlist. org > . Acesso em 20 Jul 2013.

Judd, W.S.; Campbell, C.S.; Kellogg, E.A. \& Stevens, P.F. 2009. Sistemática vegetal: um enfoque filogenético. Artmed, Porto Alegre.

Martins, E.R. \& Lima, L.R. 2012 Flora fanerogâmica do estado de São Paulo. Instituto de Botânica 7: 250-259.

Müller, J.A. 1873. Euphorbiaceae. In: Martius, C.F.P. von \& Eichler, A.G. (eds.). Flora brasiliensis. Munchen, Wien, Leipzig. Vol. 11. Pp. 1-752.

Rossignol, L.; Rossignol, M. \& Haicour, R. 1987. A systematic revision of Phyllanthus subsection Urinaria (Euphorbiaceae). American Journal of Botany 74: 1853-1862.

Secco, R.; Cordeiro, I. \& Martins, E.R. 2013. Phyllanthaceae. In: Lista de espécies da flora do Brasil. Jardim Botânico do Rio de Janeiro. Disponível em <http://floradobrasil.jbrj.gov.br/>. Acesso em 6 Mar 2013.

Silva, M.J. \& Sales, M.F. 2007. Phyllanthus L. (Phyllanthaceae) em Pernambuco. Brasil. Acta Botanica Brasilica 21: 79-98.

Silva, M.J. \& Sales, M.F. 2008. Sinopse do gênero Phyllanthus (Phyllanthaceae) no nordeste do Brasil. Rodriguésia 59: 407-422.

Thiers, B. 2013. Index Herbariorum: A global directory of public herbaria and associated staff. New York Botanical Garden's Virtual Herbarium. Disponível em $<$ http://sweetgum.nybg.org/ih/> . Acesso em 20 Mar 2013.

Webster, G.L. 1956. A monographic study of the West Indian species of the Phyllanthus L. Journal of the Arnold Arboretum 37: 91-122.

Webster, G.L. 1957. A monographic study of the West Indian species of the Phyllanthus L. Journal of the Arnold Arboretum 38: 51-79.

Webster, G.L. 1959. Phyllanthus L. Anais Botânicos do Herbário Barbosa Rodrigues 11: 164-170.

Webster, G.L. 1970. Revision of the Phyllanthus (Euphorbiaceae) in the continental United States. Brittonia 22: 44-76. 
Webster, G.L. 2001. Synopsis of Croton and Phyllanthus (Euphorbiaceae) in Western Tropical Mexico. Contributions from the University of Michigan Herbarium 23: 353-388.

Webster, G.L. 2002a. Three new sections and a new subgenus of Phyllanthus (Euphorbiaceae). Novon 12: 290-298.

Webster, G.L. 2002b. A synopsis of the Brazilian taxa of Phyllanthus section Phyllanthus (Euphorbiaceae). Lundellia 5: 1-26.
Webster, G.L. 2003. A synopsis of the Phyllanthus section Nothoclema (Euphorbiaceae). Lundellia 6: 9-36.

Wurdack, K.J.; Hoffman, P.; Samuel, R.; Bruijin, A.; Bank, M.V. \& Chase, M.W. 2004. Molecular phylogenetic analysis of Phyllanthaceae (Phyllanthoideae pro parte, Euphorbiaceae sensu lato) using plastid rbcL DNA sequences. American Journal of Botany 91: 1882-1900.

\section{Lista de exsicatas}

Aguillar 128 (18), R100007 (18), Altamiro 36 (9), Alves, M. 130 (4), 205 (17), 333 (17), R169350 (17), Amorim, A.M. 3377 (8), Andrade, A.G. 1877 (4), Andrade, J.C. R161216 (2), Andreata, R.H.P. 541 (17), Angeli, C. 54 (17), Araujo, D.S.D. 52 (4), 700 (4), Araújo, I.A. 96 (9), Barria, L. 98 (9), Barros, A.A.M. 1663 (17), 2569 (17), Barros, W.D. 1119 (17), Batista, H.P. 167 (4), Boechat, A.P. 1 (14), Bovini, M.G. 419 (17), 1110 (11), 2601 (9), 2752 (9), Brade, A.C. 10322 (2), 10455 (17), 11002 (4), 11703 (18), 12664 (9), 13925 (9), 15575 (10), 15848 (8), 17440 (9), 19465 (17), 20526 (14), 9278 (9), Braga, J.M.A. 529 (9), 3574 (17), Bride Jr, K.J.H. 1719 (16), Brito, D.L. 65 (13). Caell, P.S.J. RB86769 (9), Campêlo, C.R. 869 (18), Campos, D.L. 51 (3), 53 (18), 54 (18), 55 (18), 56 (3), 57 (18), 59 (3), 60 (3), 61 (3), 62 (18), 63 (18), 64 (3), 65 (18), 66 (18), 68 (13), 69 (18), 70 (20), 71 (20), 72 (20), 73 (20), 75 (20), 76 (20), 77 (20), 78 (20), 79 (20), 80 (20), R18535 (18), R185357 (18), R185358 (3), R185730 (18), R185734 (18), R187642 (3), Carauta, J.P.P. 3249 (17), 7503 (18), R157987 (14), Castellanos, A. 24356 (18), R197678 (18), Christo, A.G. 344 (18), Constantino, R. RB7638 (11), Cordeiro, I. 2790 (17), 2994 (9), Correia, C.M.B. 129 (9), Demuner, V. 1397 (5), Dias, I.S. RBR19249 (18), Duarte, A.P. 4120 (17), 4168 (17), 8664 (11), Egler, W. 33 (13), 32 (18), 34 (20), 35 (18), Ehrendorfer, F. 73905-22 (2), Eiten, G. 6261 (17), 7204 (17), 7206 (17), 7875 (18), Emmerich M. 2856 (17), 2855 (1), 3683 (15), 37267 (13), 4822 (13), R157953 (14), R157970 (9), Emygdio, L. 353 (13), Emygdio, L.M. Filho 5353 (11), Farney, C. 623 (17), Fernandes, H.Q.B. 2735 (6), Ferreira, V.F. 1258 (15), Fontella, P.J. 417 (4), Forzza, R.C. 2818 (17), Freire R100401 (18), Galvão, M.N. R204502 (18), Goes, O. 1054 (13), 1071 (18), 133 (17), 310 (17), 857 (15), RB49895 (18), RB49895 (18), RB80920 (13), Gomes 1204 (17), Gomes, A.A. RBR6277 (18), Guimarães, E. 30 (17), Hatschbach, G. 11408 (17), 45183 (9), Hermes, W. 5705 (4), 5874 (4), Hoehne, W. 5560 (17), 5705 (4), 5705 (4), 5874 (4), 5874 (4), Hoehnea, F.C. 291 (18), SP17322 (13), SP17418 (17), SP25069 (17), SP5692 (17), Ichaso, C.L.F. 32 (17), Jesus, J.A. 2058 (18), Jouvin, P.P. 212 (18), 227 (14), Kirkbride, J.H. RB168962 (16), Klein, V.L.G. 1041 (17), Krieger, P.L. 9605 (9), 10454 (4), 14743 (13), Kuhlmann, J.G. 37 (1), 6545 (7), 100500 (18), R100435 (18), R100449 (18), R100491 (3), R100506 (4), R1 10498 (18), RB111186 (4), RB137909 (1), RB20300 (15), HB111184 (19), Lampaie, A. 37 (18), Lanna, J.P. 230 (17), Lanze, A. 1693 (3), 1720 (4), 1768 (4), Larcher, B. 14743 (13), Leitão, F. 28 (18), Leonello, A.C. RB458260 (14), Lima, H.C. 2521 (13), 2578 (19), 5888 (15), 5956 (11), Lima, S. 194 (12), 13257 (17), 14207 (18), 14208 (17), RB26022 (9), Lindeman, J. 40 (17), Lisboa, A. RB2705 (13), RB2732 (11), RB4666 (15), Lúcio, K. R200872 (18), Lutz, A. 496 (17), 753 (17), 812 (17), Lutz, B. 584 (17), M.C.C. 5 (17), Maas, P.J.M. 3267 (17), 3411 (17), Machado, A.F.P. SP445084 (18), Maia, V.C.R. R18504 (18), R199124 (18), Marquete, R. 88 (19), 945 (17), Martinelli, G. 489 (17), 1665 (9), 6132 (11), 9056 (17), 10372 (17), 10403 (8), 10681 (6), 10773 (2), 11810 (9), Martins, L.G.S. 178 (18), Mass, P.J.M. 3137(4), Mautone, L. 42 (14), Mello, D. 22 (13), Mello, E.L. Filho 546 (17), Monteiro, H. 106 (13), 439 (18), 889 (18), 892 (14), 936 (13), 1057 (18), 1533 (18), 2099 (18), 2328 (18), 2344 (13), 2750 (18), 3260 (13), 3334 (18), 3347 (18), 3359 (18), 3567 (18), 3601 (18), 4211 (13), 4214 (18), 6256 (18), RBR6248 (18), RBR6267 (9), RBR6268 (13), RBR6288 (9), RBR6291 (13), Monteiro, M.A.B.M. RB68463 (18), Moraes, L. R204503 (18), Moraes, M. 226 (18), Occhioni, P. 172 (19), 173 (19), 174 (17), 427 (18), 590 (19), 1222 (2), Oliveira, A.E.S. 255 (17), Pabst, G.F.J. 5611 (17), 5707 (17), 6779 (17), 8933 (18), Paciornik, E.F. 126 (18), Parajara, R.L.G. RBR28765 (18), Patzlaff R. 13 (13), 82 (18), Pereira, A.B. 175 (17), Pereira, C. 59 (13), 69 (2), Pereira, E. 51 (2), 1770 (17), 1771 (17), 219 (9), 3981 (17), 4031 (18), 5752 (4), 5752 (4), 6996 (9), 6997 (2), 723 (17), Pereira, O.J. 769 (13), Pessoa, S.V.A. 233 (9), 753 (11), Pinto, L.J.S. 480 (17), 497 (13), 499 (18), 836 (13), 499 (18), Pinto, R.B. 146 (2), Pirani, J.R. 1031 (11), Poland, C. 6624 (11), Porte, P.C. RB10338 (9), Ramalho, C. RBR6247 (13), RBR6249 (18), Rego, S.A. 1310 (18), Reitz 2643 (7), Rente, E.C. 457 (18), Rezende, G.S.Z. 34 (11), 198 (13), Rizzini 75 (17), 671 (16), RB163779 (9), Rodarte, A. 4Ad (18), Rosa, M. R52232 (17), Saint-Hilaire, A. 743 (5), Sampaio, A.J. 1553 (18), 4868 (13), 7847 (18), R99330 (18), R99349 (18), Sampaio, A. 1415 (18), 1438 (18), 3058 (14), 3288 (14), 4686 (2), 4687 (2), 4768 (2), 8578 (18), Santos, M.C.F. 238 (17), 388 (17), Santos, M.G. 667 (14), Santos, N. 233 (4), Schawacke, P. 4/916 (1), 7107 (4), R98801 (1), R100442 (13), Silva Neto, S.J. 1526 (9), Silva, I.M. 305 (18), 320 (13), 687 (18), Silva, R.C.C. 14 (17), Somner, G.V. 696 (18), Souza, A. 1576 (13), 1975 (14), 1994 (14), 2174 (13), 2243 (13), 241 (4), 322 (4), 542 (4), R175183 (17), R209342 (18), Souza, P.J. 5970 (17), Strang, H. 965 (2), 333 (16), Sucre, D. 1372 (18), 1372 (3), 1555 (17), 1829 (18), 2059 (18), 2340 (18), 3418 (17), 4483 (15), 4718 (19), 5756 (2), 9648 (13), 10696 (17), Sylvestre, L. 142 (17), Thomas, W.W. 6165 (4), Ule, E. 213 (2), 3279 (14), 4371 (16), R100339 (17), R100444 (18), R100490 (20), Usteri, A.P. SP13717 (14), Valente, M.C. 25 (17), Valle, L.S. R185729 (18), Vattimo, I. RB176681 (18), RB176682 (18), Vaz, A.M.S. F. 648 (9), 723 (9) Vianna, C. 59 (17), Vianna, S.F. 371 (17), 424 (17), Vidal, J. R107705 (18), R108311 (13), R157986 (18), Vidal, W.N. 3 (18), Vieira, C.M. 77 (9), 215 (15), 783 (17), Vieira, M.F. 529 (17), Webster, G. 25434 (17), Xavier, L. RBR6270 (13), Zysco, C.C. 314 (3). 